\title{
OBTENÇÃO E CARACTERIZAÇÃO DE CONCENTRADO E ISOLADO PROTÉICO DE TORTA DE CASTANHA-DO-PARÁ
}

\author{
MARIANA MICOTTI DA GLÓRIA \\ Economista Doméstica
}

Orientadora: Prof ${ }^{a}$ Dr $^{\mathrm{a}}$ MARISA A. B. REGITANO D'ARCE

\begin{abstract}
Dissertação apresentada à Escola Superior de Agricultura "Luiz de Queiroz", Universidade de São Paulo, para obtenção do título de Mestre em Ciências. Área de Concentração : Ciência e Tecnologia de Alimentos.
\end{abstract}

PIRACICABA

Estado de São Paulo - Brasil

Novembro de 1996 
Dados Internacionais de Catalogação na Publicação (CIP) DIVISÃo DE BIBLIOTECA E DOCUMENTAÇÃO - Campus "Luiz de Queiroz"/USP

Glória, Mariana Micotti da

Obtenção e caracterização de concentrado e isolado protéico de torta de castanha-do-Pará / Mariana Micotti da Glória. - - Piracicaba, 1996.

$71 \mathrm{p}$.

Dissertação (mestrado) - Escola Superior de Agricultura Luiz de Queiroz, 1997.

Bibliografia.

1. Alimento concentrado protéico 2. Castanha-do-Pará - Subproduto 3. Torta de castanha-do-Pará - Tecnologia 1. Titulo. 


\section{OBTENÇÃO E CARACTERIZAÇÃO DE CONCENTRADO E ISOLADO PROTÉICO DE TORTA DE CASTANHA-DO-PARÁ.}

\section{MARIANA MICOTTI DA GLÓRIA}

Aprovada em 31.01 .97

Comissão julgadora

Prof ${ }^{a} r^{2}$ Marisa A. B. Regitano d'Arce ESALQ/USP

Prof. Dr. Luiz Eduardo Gutierrez

ESALQ/USP

Prof $^{a} \mathrm{Dr}^{2}$ Maricê Nogueira de Oliveira

FCF/USP

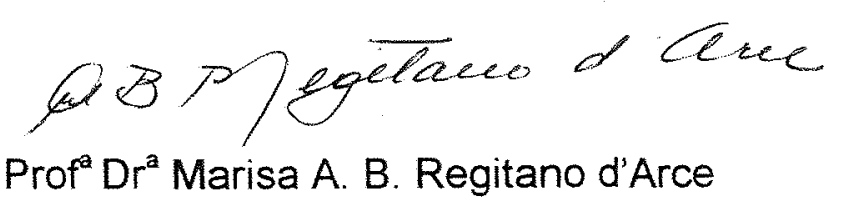




\section{DEDICO}

Aos meus pais,

Nadir e Enid 


\section{AGRADECIMENTOS}

À Prof ${ }^{\mathrm{a}} \mathrm{Dr}^{\mathrm{a}}$. Marisa A. B. Regitano d'Arce, pela oportunidade, confiança e atenção oferecidos.

À Escola Superior de Agricultura "Luiz de Queiroz"- ESALQ/USP e a CAPES, pelos recursos técnicos e financeiros indispensáveis para a realização deste trabalho.

À $\operatorname{Prof}^{a} \operatorname{Dr}^{a}$ Marilia Oetterer pelos conselhos e empréstimo de equipamentos algumas vezes necessários.

Aos amigos e conselheiros Carlos Magno Evangelista, Érika M. R. Gutierrez, Fabiana M. de Siqueira, Maria F. A. Prado, Silvia M. F. Carpi, Renata de Paula Assis Bombo, Thais M. F. de Souza Vieira.

Ao Carlos Cesar Alves, técnico do Laboratório de Bromatologia do Departamento de Zootecnia da ESALQ/USP, pelas análises de teor de fibras.

À Bibliotecária Beatriz Helena Giongo pela ajuda na padronização das referências bibliográficas

À Prof ${ }^{a} \mathrm{Dr}^{\mathrm{a}}$. Ursula M. Lanfer Marquez, do Laboratório de Análise de Alimentos da Faculdade de Ciências Farmacêuticas - USP, pela realização da análise de aminoácidos.

Aos meus pais e irmãos pelo amor e apoio.

A todas as pessoas que, direta ou indiretamente, contribuiram para a realização deste trabalho. 


\section{SUMÁRIO}

Página

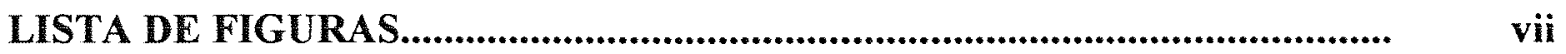

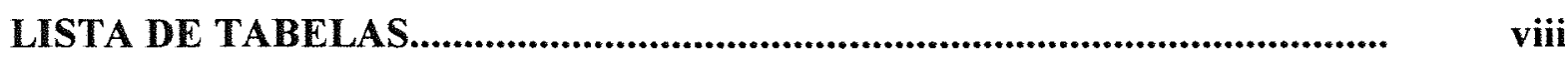

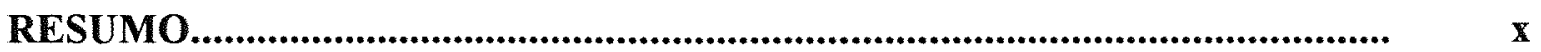

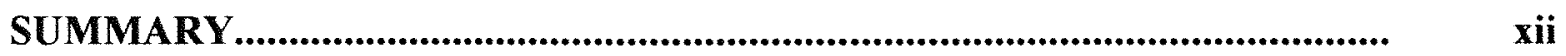

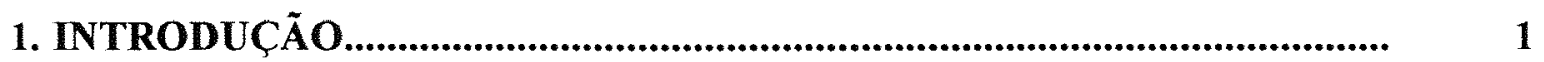

2. OBJETIVOS

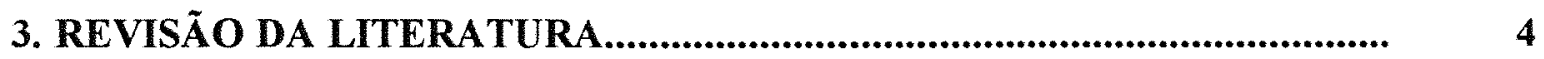

3.1. A castanha-do-pará................................................................................

3.2. Óleo da castanha-do-pará................................................................. 5

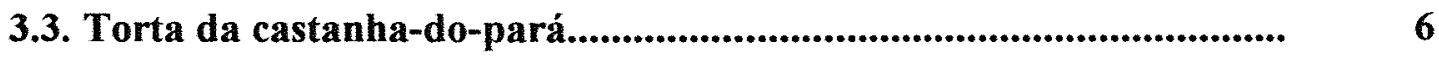

3.4. Torta desengordurada da castanha-do-pará........................................... 8

3.5. Proteina da castanha-do-pará.................................................................

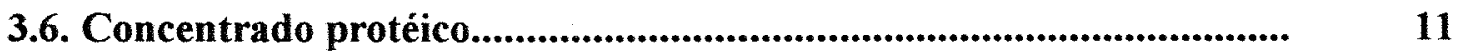

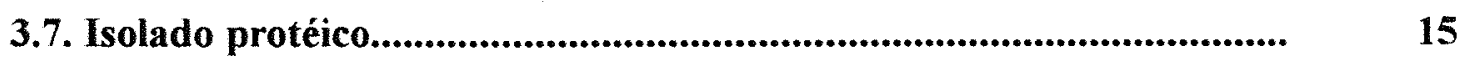

3.8. Propriedades funcionais dos concentrados e isolados protéicos......... 16

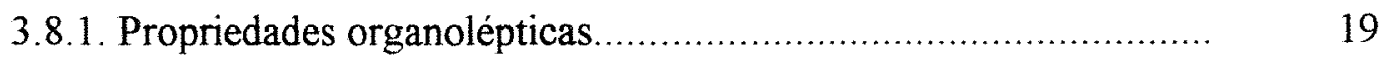

3.8.2. Propriedades fisicas........................................................... 19

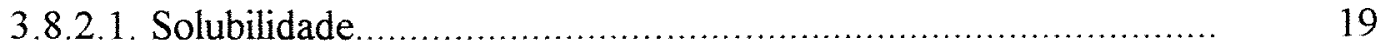

3.8.2.2. Absorção espontânea de água …............................................ 22

3.8.3. Propriedades de superficie .................................................... 23

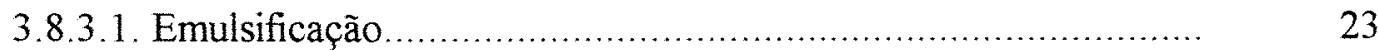


3.8.3.2. Capacidade de formação de espuma......................................... 24

3.8.4. Propriedades reológicas..................................................... 25

4. MATERIAIS E MÉTODOS...................................................................... 26

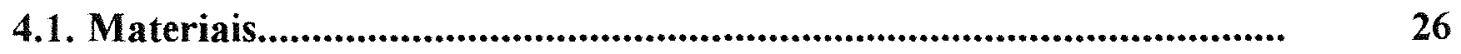

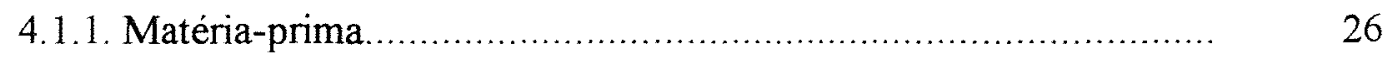

4.1.2. Torta desengordurada de castanha-do-pará................................ 26

4.1.3. Concentrado protéico de torta desengordurada de castanha-dopará - PROPARÁ.

4.1.4. Isolado protéico de torta desengordurada de castanha-do-pará -

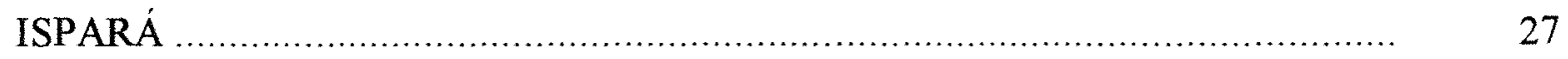

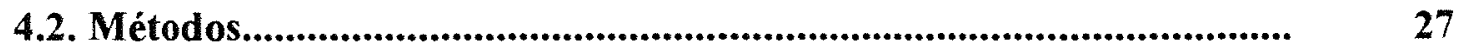

4.2.1. Determinação do processo mais adequado para obtenção do concentrado protéico de torta de castanha-do-pará (CPTCP) e do isolado protéico

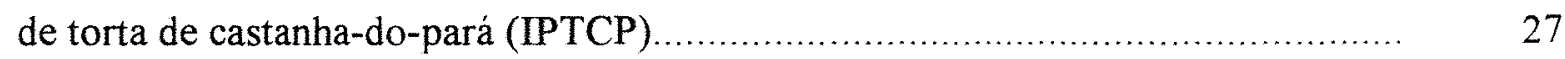

4.2.1.1. Ensaio 1 - Obtenção do Concentrado....................................... 28

4.2.1.2. Ensaio 2 - Obtenção do Concentrado..................................... 29

4.2.1.3. Ensaio 3 - Obtenção do Isolado ............................................. 31

4.2.1.4. Extração do óleo da torta de castanha-do-pará........................ 33

4.2.1.5. Ensaio 4 - Obtenção do Concentrado........................................ 32

4.2.1.6. Ensaio 5 - Obtenção do Isolado .......................................... 33 
4.2.2. Obtenção do concentrado protéico de torta desengordurada de

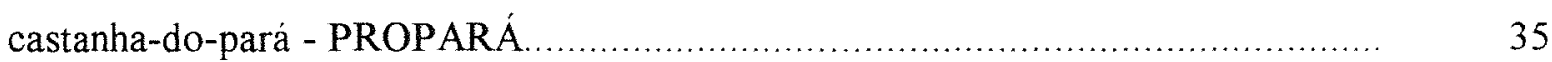

4.2.2.1. Precipitação das proteinas........................................ 35

4.2.2.2. Separação dos constituintes solúveis.............................. 35

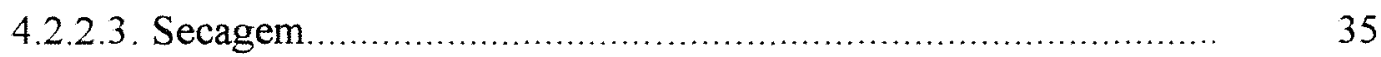

4.2.2.4. Trituração........................................................ 35

4.2.3. Obtenção do isolado protéico de torta desengordurada de

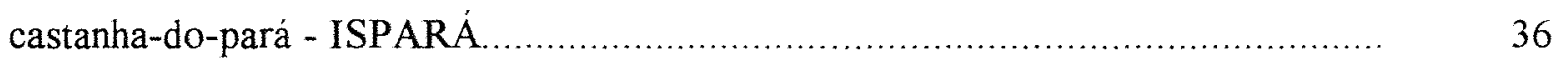

4.2.3.1. Extração das proteinas........................................... 36

4.2.3.2. Separação dos resíduos insolúveis................................. 37

4.2.3.3. Precipitação do extrato de proteinas solúveis...................... 37

4.2.3.4. Separação do precipitado dos constituintes solúveis.............. 37

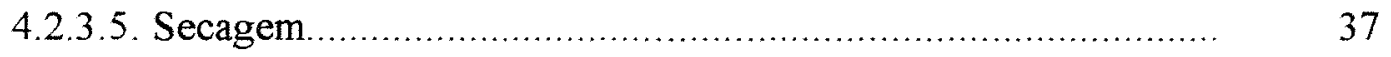

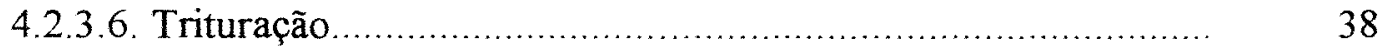

4.2.4. Análises químicas de caracterização ............................... 38

4.2.4.1. Teor de umidade ....................................................... 39

4.2.4.2. Teor de proteína bruta....................................... 39

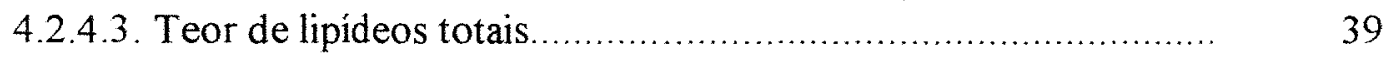

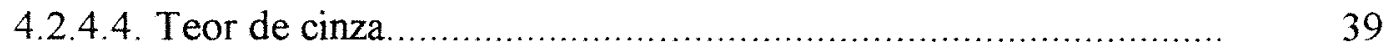

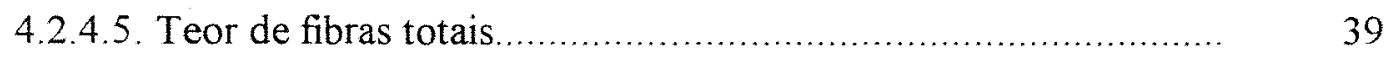

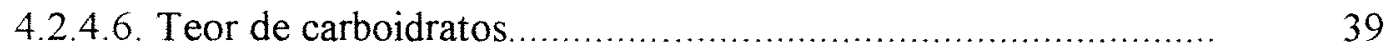


4.2.4.7. Perfil aminoacídico....................................................... 40

$\begin{array}{ll}\text { 4.2.4.8.Análise estatística } & 40\end{array}$

4.2.5. Propriedades funcionais ...................................................... $\quad 40$

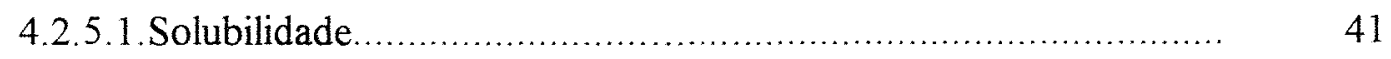

4.2.5.2. Capacidade de absorção de água.......................................... 41

4.2.5.3. Capacidade de absorção de óleo............................................. 42

4.2.5.4. Capacidade de formação de espuma....................................... 42

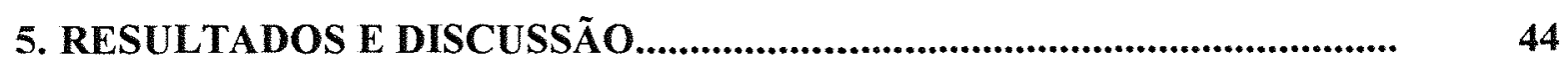

5.1. Torta integral.............................................................................................

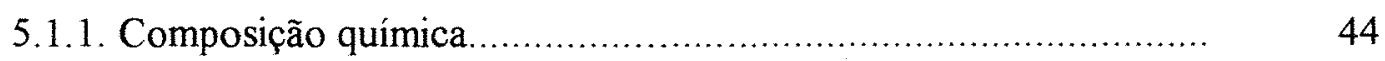

5.1.2. Produtos obtidos com a torta integral através do estudo das

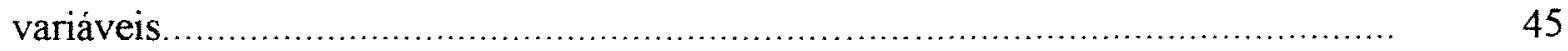

5.1.2.1. Ensaio 1 - Obtenção do Concentrado ................................... 45

5.1.2.2. Ensaio 2 - Obtenção do Concentrado..................................... 46

5.1.2.3. Ensaio 3 - Obtenção do Isolado .............................................. 48

5.2. Torta desengordurada de castanha-do-pará (TDCP) extração e

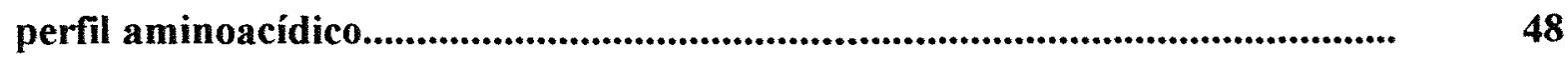

5.2.1. Ensaio 4 - Obtenção do Concentrado...................................... 50

5.2.2. Ensaio 5 - Obtenção do Isolado ............................................... 51

5.3. Concentrado protéico de torta desengordurada de castanha-do-

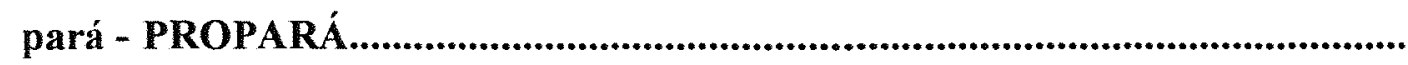


5.4. Isolado protéico de torta desengordurada de castanha-do-pará -

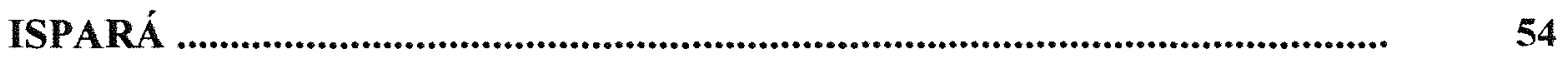

5.5. Propriedades funcionais...................................................... 55

5.5.1 Solubilidade do nitrogênio.................................... 56

5.5.1.1. Torta integral e torta desengordurada de castanha-do-pará...... 56

5.5.1.2. Concentrado e isolado protéico de TDCP (PROPARÁ e

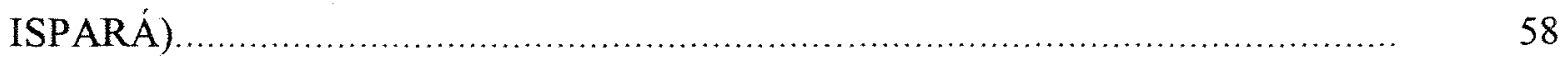

5.5.2. Absorção de água.................................................... 61

5.5.3. Absorção de óleo ............................................... 62

5.5.4. Capacidade de formação de espuma e estabilidade ................... 63

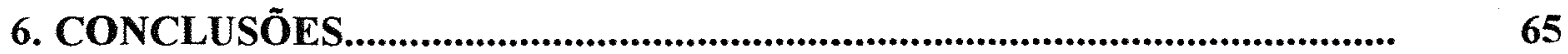

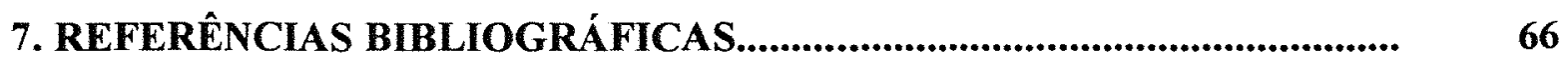




\section{LISTA DE FIGURAS}

Página

Figura 1. Obtenção do concentrado protéico de TCP com variação da proporção matéria-prima/sol. de $\mathrm{HCl}$ de precipitação da proteína e do modo separação do precipitado/material solúvel, utilizando a torta integral.

Figura 2. Obtenção do concentrado protéico de TCP, utilizando etanol (Et-OH) como agente precipitador de proteina, a partir da torta integral.

Figura 3. Obtenção do isolado protéico da TCP com variação do $\mathrm{pH}$ de precipitacão da proteína, utilizando a torta integral.

Figura 4. Obtenção da torta desengordurada de castanha-do-pará.

Figura 5. Obtenção do concentrado protéico de TDCP com variação do tempo de agitação, utilizando a torta desengordurada de castanhado-pará

Figura 6. Obtenção de isolado protéico de TDCP com variação do tempo de agitação e do pH de extração protéica, com a torta desengordurada de castanha-do-pará.

Figura 7. Processo de obtenção do PROPARÁ.............................................. 36

Figura 8. Processo de obtenção do ISPARÁ............................................... 38

Figura 9. Curva de solubilidade da torta integral de castanha-do-pará............. 57

Figura 10. Curva de solubilidade da torta desengordurada de castanha-do-pará. 58

Figura 11. Curva de solubilidade do PROPARÁ................................................ 60

Figura 12. Curva de solubilidade do ISPARÁ.................................................. 60 


\section{LISTA DE TABELAS}

Página

Tabela 1. Composição centesimal da castanha-do-pará.

Tabela 2. Comparação dos aminoácidos encontrados na castanha-do-pará descascada e na proteína padrão da FAO (1970).

Tabela 3. Composição química da torta integral.

Tabela 4. Caracterização dos concentrados protéicos de TCP através da variação do $\mathrm{pH}$ de precipitação da proteina e do modo de separação do precipitado/material solúvel, utilizando a torta integral (ENSAIO 1).

Tabela 5. Caracterização dos concentrados protéicos de TCP com variação do agente precipitante da proteina, utilizando a torta integral. (ENSAIO 2)

Tabela 6. Caracterização dos isolados protéicos de TCP obtidos através de variação do $\mathrm{pH}$ de precipitação da proteina, utilizando a torta

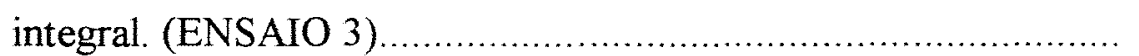

Tabela 7. Composição quimica da torta desengordurada de castanha-dopará desengordurada, obtida através dos testes com os solventes hexano (à temp. ambiente), Et-OH $99^{\circ} \mathrm{GL}$ (a $70^{\circ} \mathrm{C}$ ) e Et-OH $99^{\circ} \mathrm{GL}\left(\mathrm{a} 70^{\circ} \mathrm{C}\right)$ em duas etapas.

Tabela 8. Composições aminoacídica da TCP desengordurada com hexano...

Tabela 9. Caracterização dos concentrados protéicos de TDCP com solvente hexano, variando o tempo de agitação. (ENSAIO 4)...... 
Tabela 10. Caracterização dos isolados protéicos de TDCP obtidos através da variação do $\mathrm{pH}$ de extração de proteina e do tempo de agitação. (ENSAIO 5)

Tabela 11. Composição química do PROPARÁ com aplicação das melhores condições estabelecidas nos ensaios preliminares. (ENSAIO 6).....

Tabela 12. Composição química do ISPARÁ com aplicação das melhores

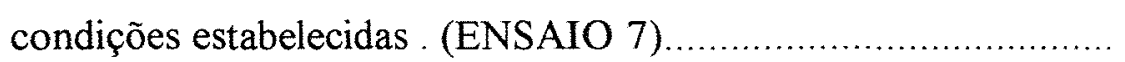

Tabela 13. Absorção de água e de óleo dos produtos de castanha-dopará.

Tabela 14. Capacidade de formação e estabilidade da espuma dos produtos de castanha-do-pará 


\title{
OBTENÇÃO E CARACTERIZAÇÃO DE CONCENTRADO E ISOLADO PROTÉICO DE TORTA DE CASTANHA-DO-PARÁ
}

\author{
Autora: MARIANA MICOTTI DA GLÓRIA \\ Orientadora: Prof ${ }^{\mathrm{e}} \mathrm{Dr}^{\mathrm{a}}$ MARISA A.B. REGITANO-D'ARCE
}

\section{RESUMO}

A torta da castanha-do-pará, rica em proteínas, é o residuo da extração de óleo, por prensagem das castanhas descascadas. Sua utilização é um meio de se aumentarem os recursos alimentares da população da região amazonica

Métodos de obtenção de concentrado e isolado protéico de torta de castanha-do-pará foram estudados a fim de se conseguir uma metodologia prática e econômica para tais produtos, mas foi somente com a extração do óleo da torta, com solvente hexano, que se conseguiu produzir concentrado e isolado com $59 \%(\% \mathrm{~N} \times 5,46)$ e $81 \%(\% \mathrm{~N} \times 5,46)$ de proteína, respectivamente.

A torta desengordurada de castanha-do-pará, juntamente com os produtos, concentrado e isolado protéico, foram investigados quanto a sua possibilidade de aplicação em alimentos, através de avaliação das propriedades funcionais (solubilidade, absorção de água e óleo, 
capacidade de formação de espuma). Para isso utilizou-se um sistema de modelo simples, de resposta rápida e de baixo custo.

$\mathrm{O}$ isolado apresentou boa formação de espuma e no tocante as outras propriedades funcionais analisadas, tanto a torta desengordurada de castanha-do-pará como o concentrado e o isolado protéico apresentaram boas condições de funcionalidade. 


\title{
OBTENTION AND CHARACTERIZATION OF BRAZIL NUT CAKE PROTEIN CONCENTRATE AND ISOLATE
}

\author{
Authoress: MARIANA MICOTTI DA GLÓRIA \\ Adviser: $\operatorname{Prof}^{\mathrm{a}} \mathrm{Dr}^{\mathrm{a}}$ MARISA A.B. REGITANO-D'ARCE
}

\section{SUMMARY}

Brazil nut cake, rich in proteins, is the nut pressing for oil production residue and may be used as food for the Amazon region population.

Methods for obtention of protein concentrate and isolate were studied in order to achieve a practical and economic methodology. Cake defatting was necessary and hexane oil extracted cakes yielded $59 \%$ protein $(\mathrm{N} \% \times 5,46)$ concentrate and $81 \%$ protein $(\mathrm{N} \% \times 5,46)$ isolate.

Functional properties of the concentrate and isolate were evaluated. A simple model system was adopted for indication of protein use in foods due to its low cost and low time consumption. Protein isolate presented good foaming capacity. Regarding solubility, oil and water absorption, all products, cake, concentrate and isolate, presented good functionality. 


\section{INTRODUÇÃO}

A castanha-do-pará é classificada pelo Ministério da Agricultura, para efeito do comércio internacional como Noz do Brasil. É também conhecida como "Brazil nut" pelos ingleses e como "Noix du Brésil" pelos franceses.

O Brasil ocupa a privilegiada posição de produtor quase exclusivo da castanha-do-pará, figurando os Estados do Pará e do Amazonas como os maiores produtores.

A produção da castanha-do-pará, que é estimada em vinte e uma mil toneladas anuais, é na sua grande maioria exportada para os EUA e Reino Unido, onde a utilizam em produtos de confeitaria, doces e chocolates. A exportação é feita com a castanha inteira e "in natura", estando quebradas ou apresentando defeitos são logo desprezadas para este comércio e, alternativamente, podem servir de matéria-prima para a extração de óleo.

O óleo extraído por prensagem das castanhas quebradas é utilizado pela população local e o resíduo, a torta, para ração animal. Há anos atrás o farelo de soja também era usado somente para alimentar animais e, hoje em dia, após o reconhecimento de seu valor tanto através das propriedades funcionais como nutricionais, iniciou-se a incorporação em produtos alimentícios. 
A torta da castanha-do-pará é comprovadamente uma fonte de proteína e poderia vir a fazer parte da dieta da população da região amazônica, se lhe fosse aplicado processamento adequado.

Utilizando etapas simples e de baixo custo de processamento consegue-se desenvolver, com a torta da castanha-do-pará, dois produtos com altas concentrações de proteinas, próximos ao concentrado e isolado protéico. Com equipamentos e processos mais aprimorados, os concentrados e os isolados protéicos da torta da castanha-do-pará apresentam propriedades funcionais qualificadas e poderão ser incorporados a vários grupos de produtos alimentícios, tanto como substitutos de ingredientes, como um novo ingrediente acrescentando ao produto novos atributos, aumentando-se, em ambos os casos, valor nutritivo 


\section{OBJETIVOS}

Os objetivos desse trabalho foram a obtenção e a caracterização do concentrado e do isolado protéico da torta de castanha-do-pará resultante da prensagem de castanhas descascadas em mini-prensas tipo "Expeller", buscando definir os parâmetros tecnológicos para a sua produção, bem como avaliar suas características químicas e propriedades funcionais. 


\section{REVISÃO DA LITERATURA}

\subsection{A castanha-do-pará}

A espécie botânica que dá origem à castanha-do-pará, é classificada como Bertholletia excelsa.

A castanheira-do-pará tem aproximadamente 50 metros de altura e até 2 metros de diâmetro na base. O fruto, denominado, "ouriço", é uma cápsula (pixídio) de forma quase esférica, medindo de 8 a 15 centímetros de diâmetro e contendo de 12 a 30 sementes (castanhas) angulosas, mais ou menos triangulares.

A produção de castanhas-do-pará que consistia do extrativismo, vem sendo substituída pelo plantio racional com mudas enxertadas, espaçamentos e tratos culturais adequados, defesa fitossanitária e estudos de solo, esperando com isso, obter melhor aproveitamento da produção e maior estabilidade dos produtos obtidos.

O endosperma das castanhas é uma fonte rica de lipídeos e proteínas, apresentando entre 60 a $70 \%$ de óleo e 15 a $20 \%$ de proteínas, podendo ser consumida "in natura" ou como ingrediente em grande variedade de receitas.

A Tabela 1 apresenta valores comparativos referentes à composição centesimal da castanha-do-pará descascada onde se pode verificar a sua relativa 
uniformidade de composição entre os trabalhos consultados. As pequenas variações encontradas nos dados da Tabela 1 podem ser devido às variações agronômicas e/ou culturais entre as amostras.

Tabela 1. Composição centesimal da castanha-do-pará

\begin{tabular}{l|l|l|l|l}
\hline Componentes (\%) & $\begin{array}{l}\text { Pechnik } \\
1950\end{array}$ & et $\begin{array}{l}\text { al. } \\
\text { Bressani, 1961 }\end{array}$ & $\begin{array}{l}\text { Elias } \\
\text { Pereira, 1976 }\end{array}$ & $\begin{array}{l}\text { Woodroof, } \\
1979\end{array}$ \\
\hline umidade & $\mathbf{3 , 0 0}$ & $\mathbf{2 , 0 0}$ & $\mathbf{2 , 4 3}$ & $\mathbf{2 , 0 0}$ \\
proteina (N x 6,25) & $\mathbf{1 6 , 4 0}$ & $\mathbf{1 6 , 3 0}$ & $\mathbf{1 5 , 8 5}$ & $\mathbf{1 6 , 3 0}$ \\
lipideos & $\mathbf{6 9 , 3 0}$ & $\mathbf{6 8 , 3 0}$ & $\mathbf{6 5 , 4 5}$ & $\mathbf{6 8 , 3 0}$ \\
fibra & $\mathbf{4 , 6 0}$ & $\mathbf{2 , 6 0}$ & $*$ & $\mathbf{6 , 6 0}$ \\
carboidratos totais & $\mathbf{3 , 2}$ & $*$ & $*$ & $*$ \\
sais minerais & $\mathbf{3 , 5}$ & $*$ & $*$ & $\mathbf{3 , 6 1}$ \\
\hline
\end{tabular}

Obs.: * dado não disponivel no trabalho

\section{2. Óleo da castanha-do-pará}

O óleo da castanha-do-pará, segundo Durão (s.d.), é doce e de gosto agradável.

É um óleo líquido à temperatura ambiente, de cor amarelo claro, com sabor e aroma agradáveis, característicos da castanha-do-pará (Pechnik et al., 1950).

Estudos biológicos em ratos indicaram que o valor de digestibilidade do óleo da castanha-do-pará e sua influência no crescimento são comparáveis aos vários óleos e gorduras utilizados na indústria de alimentos (Elias \& Bressani, 1961). 
O óleo da castanha não é fabricado em escala comercial e geralmente é obtido a partir de castanhas quebradas que não são aceitas no mercado externo. Como regra geral, o óleo da castanha é extraido por prensas mecânicas ou hidráulicas. A prensagem é uma alternativa barata de extração do óleo, uma vez que a castanha é muito rica em lipídeos. Desse processo resulta um resíduo que ainda apresenta consideráveis quantidades de óleo, denominado torta. A torta da castanha-do-pará pode apresentar sabor e aroma semelhantes ao da castanha fresca dependendo das condições de preparo para a prensagem e tem conservação prolongada quando armazenada em ambiente refrigerado.

O processo de prensagem retira em média 30 a $50 \%$ do óleo total presente na castanha.

\subsection{Torta da castanha-do-pará}

Tortas, em geral, concentram o teor de proteina o que suscita o interesse em viabilizar a sua introdução na alimentação humana. $\mathrm{O}$ aumento da utilização da torta da castanha-do-pará beneficiará tanto cooperativas, que fazem uso da castanha como matéria-prima para extração de óleo, como também toda a população, com mais uma fonte de proteina na alimentação.

A determinação da composição química da torta da castanha-do-pará comprova a sua concentração protéica. Costa \& Mota (1942) analisaram a torta da 
castanha-do-pará triturada e obtiveram os seguintes resultados: umidade, 7,64\%; proteina (N x 6,25), 33,42\%; lipídeos, 38,5\%; fibras, 0,1\%; carboidratos totais, $13,64 \%$; minerais, $6,8 \%$.

Pechnik et al. (1950) alimentaram ratos com torta de castanha, com $29,2 \%$ de óleo, obtida por prensagem. Os resultados da administração de uma dieta em que $o$ constituinte protéico consistiu de torta e leite bovino foram superiores ao padrão com leite, como componente protéico único e demonstraram a boa qualidade nutricional da torta como fonte protéica e calórica na alimentação.

Rotenberg \& Iachan (1975) verificaram que a torta da castanha-do-pará desengordurada, com um teor protéico $(\% \mathrm{~N} \times 6,25)$ de $52,03 \%$, não apresentou atividade proteolítica, nem anti-tríptica.

Ao extrair o óleo da torta da castanha-do-pará com solvente, obtém-se um produto que pode ser denominado de torta desengordurada de castanha-do-pará.

Alguns pesquisadores que estudaram o valor nutritivo da castanha-do-pará propuseram introduzí-la na alimentação humana na forma de torta desengordurada. 


\subsection{Torta desengordurada da castanha-do-pará}

Os solventes que podem ser utilizados na extração do óleo são etanol, isopropanol, isobutanol, tetracloreto de carbono e hexano. O hexano é o solvente mais comumente usado pelas indústrias de extração de óleo vegetal.

É um solvente apolar, isto é, altamente hidrofóbico, por isso tem pouca habilidade de desnaturar proteínas de soja (Fukushima, 1969).

Os flocos de soja devem ser extraídos com hexano ou éter dietílico à temperatura ambiente. Vapores ou solventes como álcool e acetona devem ser evitados quando se deseja o máximo de rendimento na extração das proteinas (Smith ${ }^{1}$ et al., 1951 citados por Wolf 1972)

Antunes \& Markakis (1977) determinaram a composição química da castanha-do-pará desengordurada: umidade, $8,7 \%$; óleo, $1,0 \%$; proteína $(\mathrm{Nx} 6,25 \%)$, $54,5 \%$; cinza, $7,3 \%$; fibra, $5,9 \%$ e carboidratos, $22,6 \%$. Esses mesmos autores demonstraram, alimentando ratos, que a qualidade da proteína do feijão, uma fonte pobre de aminoácidos sulfurados, pode ser melhorada pela mistura de feijão com farinha de castanha-do-pará desengordurada, uma rica fonte de metionina. O coeficiente de eficácia protéica (CEP) do feijão foi de 1,53 e da dieta contendo $10 \%$ de proteína de feijão $\mathrm{e}$ castanha-do-pará na proporção de 80:20; $90: 10$ e 95:5, de 2,42; 2,16 e 1,93, respectivamente. O CEP da caseína é 2,5 .

\footnotetext{
SMITH, A.K.; JOHNSON, V.L.: DERGES R.E. Denaturation of soybean protein with alcohols and with acetone. Cereal Chemistry. v.28, p.325-33. 1951
} 
Menezes (1967) constatou que a farinha desengordurada da castanha-do-pará distingue-se das outras pelo seu elevado teor protéico de $33,4 \%$, recomendando-a para adição em misturas com farinhas de trigo para a fabricação de pão misto de maior valor nutritivo.

Moura \& Zucas (1981) verificaram que o CEP da mistura de três partes de proteína isolada de soja e de uma de farinha de castanha-do-pará foi superior ao CEP da proteína isolada de soja, graças aos aminoácidos sulfurados supridos pela farinha de castanha-do-pará, nos quais a proteina da soja é deficiente.

Zucas et al. (1975) concluíram que a farinha de castanha-do-pará apresenta cerca de $46 \%$ de proteínas com um perfil de aminoácidos superior ao da caseína e teor elevado de aminoácidos sulfurados totais.

\subsection{Proteína da castanha-do-pará}

Sun et al. (1987) verificaram que as nozes da castanha-do-pará contém 15$17 \%$ de proteína por peso úmido e $50 \%$ de proteína por peso seco de farinha desengordurada

Osborne (1918) denominou a globulina, principal proteina da castanha-dopará, de excelsina. A globulina é uma fração protéica que tem baixa solubilidade em água e precipita com o aquecimento e com a adição de elevadas concentrações de sais. 
Segundo Ensminger et al. (1994) e a $\mathrm{FAO}^{2}$ (1970) o aminograma das proteinas da castanha-do-pará, e principalmente, das globulinas revela teores apreciáveis de leucina, fenilalanina, metionina, valina, com destaque para a metionina (Tabela 2).

Tabela 2. Comparação dos aminoácidos essenciais encontrados na castanha-do-pará descascada e na proteína padrão da FAO (1970).

\begin{tabular}{c|c|c|c}
\hline $\begin{array}{l}\text { aminoácidos } \\
\mathrm{mg} / \text { lo0g de amostra }\end{array}$ & $\begin{array}{c}\text { Ensminger et al. } \\
1994\end{array}$ & FAO (1970) & $\begin{array}{l}\text { FAO (1970) } \\
\text { ovo ** }\end{array}$ \\
\hline Isoleucina & $\mathbf{5 9 3}$ & $\mathbf{4 7 4}$ & $\mathbf{7 7 8}$ \\
Leucina & 1129 & 1168 & $\mathbf{1 0 9 1}$ \\
Lisina & 443 & 474 & $\mathbf{8 6 3}$ \\
Metionina & $\mathbf{9 4 1}$ & $\mathbf{9 8 4}$ & $\mathbf{4 1 6}$ \\
Fenilalanina & $\mathbf{6 1 7}$ & $\mathbf{6 6 1}$ & $\mathbf{7 0 9}$ \\
Treonina & 422 & 442 & $\mathbf{6 3 4}$ \\
Triptofano & 187 & 322 & $\star$ \\
Valina & $\mathbf{8 2 3}$ & $\mathbf{7 2 9}$ & $\mathbf{8 4 7}$ \\
\hline
\end{tabular}

* dado não disponivel no trabalho

** padrão FA0 (1970) segundo Oliveira et al. 1989

A Tabela 2 revela que a castanha-do-pará tem uma proteína de excelente qualidade, pois apresenta em quantidades suficientes os aminoácidos essenciais, comparando-se com o perfil de aminoácidos da proteína de referência recomendada pela FAO, o ovo. A exceção existe para os aminoácidos isoleucina, treonina e lisina que são limitantes.

Segundo Sun et al. (1987), a castanha-do-pará é provavelmente uma das mais ricas fontes de aminoácidos sulfurados, tendo aproximadamente $8,3 \%$ de metionina e cisteína por peso de proteina.

\footnotetext{
"Amino Acid Content of Foods and Biological Data on Proteins "FAO Nutritional Studies" Roma . Itália, n.24, Food and Agriculture Organization of the United Nations. 1970.
} 
Uma maneira de ampliar o uso da proteína da torta da castanha-do-pará é através da transformação desta em concentrado e isolado protéico.

\subsection{Concentrado protéico}

Hoje em dia utiliza-se o farelo de soja resultante da extração de óleo de soja com hexano, como matéria-prima para a produção de concentrado e isolado protéico.

Os concentrados protéicos de soja são produzidos a partir do farelo desengordurado, com $50 \%$ de proteína, por um processo de extração fracionada, onde é feita a remoção de açúcares solúveis, cinzas e componentes menores. A proteína é insolubilizada e os componentes solúveis são lixiviados, até a obtenção de produtos com alto conteúdo de proteina (Santos et al., 1978; Campbell et al., 1985).

A Legislação Brasileira de Alimentos define o concentrado protéico de soja como um produto protéico com no mínimo $68 \%$ de proteína $(\% \mathrm{~N} \times 6,25)$ em matéria seca, sendo este o único tipo de concentrado classificado (ABIA, 1991).

Concentrados protéicos comerciais, na sua maioria, apresentam um total de 70\% de proteina em base seca (Meyer, 1971; Campbell et al., 1985).

O fator $(6,25)$, pelo qual se multiplica o teor de nitrogênio da amostra, origina do teor médio de $16 \%$ de nitrogênio nas proteínas, entretanto ele pode variar de 
12 a 19\%. Para a castanha-do-pará o teor protéico bruto é calculado multiplicando-se o teor de nitrogênio por 5,46 (AOAC, 1995).

Os processos básicos existentes para se obterem concentrados protéicos diferem entre si quanto ao método utilizado para insolubilizar a maior parte das proteinas do farelo e separá-las dos componentes solúveis.

Sair $^{3}$ (1959), citado por Santos (1978), descreveu um método de lavagem ácida do farelo desengordurado com solução aquosa de $\mathrm{pH} 4,5$, como meio de separar as proteinas dos constituintes solúveis. O material concentrado de proteina era depois neutralizado e seco.

A técnica utilizada para precipitar a proteina em meio ácido é baseada no fato da maioria das proteínas da soja pertencerem ao grupo das globulinas. Esse grupo de proteínas é insolúvel em água na região do seu ponto isoelétrico ( $\mathrm{pH} \mathrm{4,2} \mathrm{a} \mathrm{4,6).} \mathrm{Se} \mathrm{o} \mathrm{pH}$ estiver acima ou abaixo do ponto isoelétrico, as globulinas se dissolvem. O concentrado obtido pela lavagem ácida, com posterior neutralização, apresenta índice alto de solubilidade (Cogan et al., 1967).

Cheftel et al. (1989) constataram que a maioria das tortas ou farinhas, os procedimentos de concentração de proteína por via úmida eliminam grande parte dos fatores antinutricionais ou tóxicos de baixa massa molar (gossipol, $\alpha$-galactosideos,) mas concentra os de natureza proteica (inibidores de tripsina, hemaglutininas). Por isto, há necessidade da sua inativação mediante calor úmido, tendo em conta que este tratamento

s SAIR L. U.S. Patent 2.881.070 - Griffith Laboratories, Inc.. 1959. 
altera as propriedades funcionais dos constituintes protéicos. Frequentemente o tratamento térmico é aplicado depois que o concentrado protéico foi incorporado ao alimento formulado durante a cocção ou no processo de esterilização.

Segundo Meyer (1971), para que o produto resultante do processo, que utiliza a solução ácida, tenha alto teor de nitrogênio solúvel, é preciso que ele seja neutralizado antes da secagem. O rendimento em concentrado protéico é de cerca de $60 \mathrm{a}$ $70 \%$ do peso dos flocos desengordurados.

Strano (1987), na tentativa de obter e caracterizar um concentrado protéico de aguapé com teor de cinza reduzido, empregou lavagens, do produto seco, tanto com

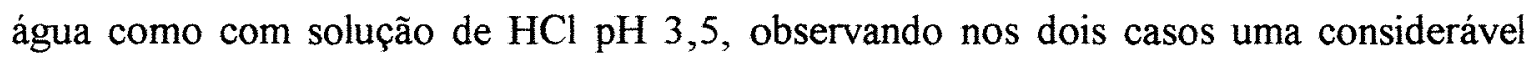
redução do teor de cinza, acompanhada de uma perda expressiva de proteína. Isto levoua à conclusão de que a lavagem do concentrado seco, nas condições testadas, embora eficaz na remoção da cinza, não devia ser usada, devendo as operações de lavagem necessárias serem feitas durante as etapas do processamento.

Bickoff et al. (1975), que estudaram a obtenção de concentrado de folha de alfafa, verificaram que as operações de lavagem com água destilada devem fazer parte das etapas do processamento.

Bau et al. (1983) prepararam produtos protéicos de girassol incolores, utilizando ácido citrico para a lavagem do farelo. Segundo os autores, como os sais minerais aceleram a oxidação de compostos fenólicos, há necessidade do uso de um antioxidante com ação quelante como o ácido cítrico. 
Segundo Mustakas et al. (1961), um método para aumentar a concentração de proteina do farelo de soja é extrair os componentes solúveis com álcool diluído. Este método reduz a concentração de açúcar e outros componentes da farinha, solúveis em álcool, aumentando proporcionalmente, o conteúdo de proteína. Os álcoois removem substancialmente o "aroma de grão". Como as misturas de água-álcool não são satisfatoriamente removidas com os dessolventizadores convencionais sem afetar o produto, é necessário utilizar o chamado dessolventizador tipo "flash", que reduz ao mínimo o contato do farelo com o vapor à alta temperatura.

O processo água-álcool é comumente empregado para produzir proteína de soja comercial. Devido à desnaturação das proteinas pela solução aquosa de álcool, a maioria das proteínas torna-se insolúvel e permanece com os polissacarideos insolúveis (Campbell et al., 1985).

Segundo Berot et al. (1995), o farelo de algodão pode ser considerado uma matéria-prima interessante para a produção de concentrado protéico pois seus componentes indesejáveis podem ser extraídos pela água e, particularmente, pela mistura de água-etanol. A produção de concentrado protéico de algodão é muito similar ao de soja. A extração com água não é viável por causa do baixo rendimento e insuficiente remoção de pigmentos, apesar da preservação das propriedades funcionais devido ao mínimo de desnaturação protéica. Extrações com água-etanol são mais adequadas, especialmente nas concentrações de 60:40 e 70:30 v/v, que asseguram o mais alto 
rendimento e uma eficiente remoção de açúcares solúveis e pigmentos. Entretanto este processo resulta em uma significativa perda das propriedades funcionais.

Os concentrados obtidos pelos processos de lavagem com álcool apresentaram baixa solubilidade, em virtude da desnaturação da proteína pelo álcool. O concentrado obtido pela lavagem ácida e com posterior neutralização apresentou índice alto de solubilidade em água. Os concentrados protéicos obtidos por tais processos apresentaram composição química semelhante (Campbell et al., 1985).

\subsection{Isolado protéico}

Meyer (1971) definiu o isolado protéico de soja como um produto contendo no mínimo $90 \%$ de proteína $(\% \mathrm{~N}$ x 6,25) em matéria seca. A Legislação Brasileira de Alimentos considera o isolado protéico um produto com no mínimo $88 \%$ de proteina $(\% \mathrm{~N} \mathrm{x} 6,25)$ em base seca (ABIA, 1991).

A preparação do isolado protéico baseia-se na extração de proteinas dos flocos desengordurados com uma solução aquosa de grau alimentício de sais, tais como hidróxido de sódio, carbonato de sódio, fosfato de trisódio, hidróxido de cálcio e hidróxido de amônia, a qual pode variar de um $\mathrm{pH}$ perto da neutralidade para uma alcalinidade moderada. A proteína extraída é separada dos resíduos insolúveis dos flocos por instrumentos mecânicos apropriados. O extrato clarificado é em seguida acidificado a um pH de aproximadamente 4,5 para precipitar a fração de globulina, separando-a dos 
constituintes solúveis, que são açúcares, cinza e componentes menores (Meyer, 1971; Kolar et al., 1985).

As principais variáveis que afetam a extração de proteina na obtenção de produtos de qualidade aceitável e custo mínimo são a quantidade e água e matéria-prima, pH, temperatura, tempo de extração, velocidade de agitação e número de extrações (Kolar et al., 1985).

O rendimento em isolado protéico de soja varia entre 30 a $40 \%$ do peso dos flocos desengordurados (Meyer, 1971; Kolar et al., 1985).

Santos et al. (1978) descrevram a produção de um isolado protéico de soja, obtido a partir do farelo, através de uma extração alcalina, na primeira etapa, em que os constituintes insolúveis foram separados da proteína solubilizada. Na segunda etapa, o extrato contendo a proteína e os constituintes solúveis sofreram uma acidificação para precipitar as proteinas, separando-as dos demais constituintes solúveis. A separação do precipitado dos constituintes solúveis foi feita em centrífuga a $2.500 \mathrm{rpm}$, durante 5 minutos ( $1362 \times \mathrm{G})$. O precipitado foi lavado com água e novamente centrifugado.

\subsection{Propriedades funcionais dos concentrados e isolados protéicos}

Embora os concentrados e isolados proteicos sejam fontes de proteina, suas propriedades funcionais são mais valorizadas que sua contribuição nutritiva para a indústria de alimentos (Lockmiller, 1973). 
As propriedades funcionais podem ser definidas como aquelas que informam como as proteínas se comportam num sistema alimentício. A caracterização funcional pode ser encarado de diferentes maneiras. O método tradicional é o de provar o novo produto numa ampla categoria de diferentes tipos de alimentos. Essa técnica de prova consome tempo, é onerosa e fornece limitadas informações sobre a proteina. Outra alternativa é estudar um sistema-modelo simples, do qual se poderá obter a indicação referente à complexa natureza das proteínas e, então, comprovar o seu desempenho em um número restrito de alimentos (Bartholomai \& Pilosof, 1985).

Sgarbieri (1996) afirmou que quando as provas sensoriais não fazem parte do estudo, os sistemas modelos apresentam vantagens pela sua maior precisão, menor custo, podendo também representar uma economia de tempo na realização das provas.

Para a incorporação de isolados ou concentrados protéicos em alimentos salsichas, hamburgers, pães, cremes, leites, bebidas carbonatadas, etc. - eles devem possuir certas propriedades funcionais cujas exigências variam de acordo com os diferentes tipos de alimentos. Isso significa, portanto, que as propriedades funcionais, mais que o valor nutritivo, determinam a esfera de aplicação de um novo isolado ou concentrado protéico. Assim, um importante aspecto no desenvolvimento do processo de fabricação de um isolado ou concentrado protéico é o de estabelecer suas propriedades funcionais fisico-químicas (Bartholomai \& Pilosof, 1985). 
Segundo Sgarbieri (1996) as propriedades funcionais dos alimentos não dependem somente das proteinas mas também de outros componentes que entram em sua composição.

Regitano-d'Arce et al. (1994) estudaram as propriedades funcionais do farelo de girassol obtido através da extração do óleo, com etanol com quatro concentrações $\left(99^{\circ} \mathrm{GL}, 96^{\circ} \mathrm{GL}, 93^{\circ} \mathrm{GL}\right.$ e $90^{\circ} \mathrm{GL}$ ) e determinaram a solubilidade e a dispersibilidade do nitrogênio e a absorção da água e de óleo pelo farelo. A mais alta solubilidade de proteína foi encontrada no produto obtido com álcool $93^{\circ} \mathrm{GL}$; a melhor absorção de água ocorreu nos farelos produzidos com álcool a $99^{\circ} \mathrm{GL}$ e $90^{\circ} \mathrm{GL}\left(11,4 \mathrm{ml} \mathrm{H} \mathrm{H}_{2} \mathrm{O} / \mathrm{g}\right.$ proteína) e a melhor absorção de óleo foi detectada nos farelos de $96^{\circ} \mathrm{GL}$ e $99^{\circ} \mathrm{GL}(1,6 \% \mathrm{~N}$ disperso, ou rendimento de $27 \%$ ). Os farelos obtidos com soluções hidroalcoólicas mais concentradas foram indicados para produção de concentrados e isolados protéicos.

As propriedades funcionais das proteinas de oleaginosas de importância para a aplicação nos alimentos são: 1) propriedades organolépticas (cor, sabor e aroma), e 2) propriedades fisicas: a) propriedades de hidratação, dependem principalmente da interação proteína-água (solubilidade e capacidade de absorção espontânea de água), b) propriedades superficie, dependem da interação da proteina com as fases imisciveis (emulsificação, capacidade de formação de espuma e capacidade de reter lipídeos) c) propriedades reológicas, dependem da interação proteina-proteína (viscosidade, ou viscosidade aparente - não newtoniano e tixotropia) (Kinsella et al., 1985). 
Alguns dos fatores que mais afetam a funcionalidade das proteínas são tratamentos térmicos, atividade de água, $\mathrm{pH}$, tratamentos prévios (extração com solventes), constantes dielétricas do meio, propriedades inerentes da proteína (nativa ou desnaturada), métodos e condições de isolamento, grau de purificação, concentração da proteína, temperatura, composição e concentração de íons e potencial de oxido-redução.

\subsubsection{Propriedades organolépticas}

O sabor e a cor devem ser neutros e não originar sabores estranhos com outros componentes durante o processamento.

\subsubsection{Propriedades físicas}

\subsubsection{Solubilidade}

A solubilidade é medida pelo ISN (indice de solubilidade de nitrogênio - g N em solução/g de $\mathrm{N}$ total $\times 100$ ) ou pelo IDP (índice de dispersibilidade protéica - g proteína na solução/g de proteína total $\mathrm{x} 100$ ). A solubilidade das proteínas é a propriedade que dá a informação mais valiosa do seu uso potencial em bebidas e está relacionada com outras propriedades importantes. Ela é bastante dependente dos 
tratamentos prévios sofridos pela proteína, do método de extração, da concentração dos ions e do $\mathrm{pH}$ do solvente (Kinsella et al., 1985).

As características da solubilidade são muito úteis para poder determinar as condições ótimas de extração e purificação das proteínas. A solubilidade, sob distintas condições, também dá uma boa indicação das aplicações potenciais das proteínas; assim frequentemente a solubilidade protéica é a primeira propriedade funcional que se determina em cada etapa de preparação e de transformação de um ingrediente protéico (Cantoral et al., 1995).

Cantoral et al. (1995), estudando os concentrados protéicos de leguminosas (Pisum sativum, Vicia faba, Glycine max), observaram que a solubilidade protéica foi praticamente nula na região de $\mathrm{pH}$ situada em torno do seu ponto isoelétrico ( $\mathrm{pH} \mathrm{4,2} \mathrm{-}$ $4,6)$.

Hamm $^{4}$ (1966), citado por Bartholomai (1979), sugeriu que a desnaturação poderia ser claramente indicada pela diminuição na solubilidade dos isolados protéicos e, portanto, na diminuição das forças de união com água, visto que esta última e a solubilidade estão intimamente associadas.

Hermansson (1979) constatou que solubilidade e desnaturação nem sempre estão correlacionadas: “dados de alta solubilidade são algumas vezes obtidos de proteínas completamente desnaturadas".

\footnotetext{
${ }^{4}$ HAMM. R. The physiology and biochemistry of muscle as food. E.J. Briskey: R.G.Cassens: J.C. Trautman. eds. The University of Wisconsin Press. Madison. Wisc., 363p.. 1966.
} 
Hutton \& Campbell (1977) determinaram o indice de solubilidade de nitrogênio e a porcentagem de absorção de água de um concentrado e de um isolado protéico de soja com base no $\mathrm{pH}$ e na temperatura. Como sofreu maior desnaturação durante o processamento, o concentrado usado neste estudo apresentou solubilidade menor que a do isolado. Essa diferença de solubilidade pode ser explicada também pela presença de polissacarídeos no concentrado, que podem competir com as proteínas pela água disponivel. A baixa solubilidade em $\mathrm{pH}$ 5,0 refletiu o comportamento típico das proteinas nas proximidades do ponto isoelétrico.

Wolf \& Cowan (1971) apresentaram a curva de retenção de água em função do $\mathrm{pH}$ das proteínas da soja, seguida pela curva de solubilidade em função do $\mathrm{pH}$. Ambas, solubilidade e retenção de água, foram mínimas no ponto isoelétrico $(\mathrm{pH} 4,5)$ e aumentaram assim que o $\mathrm{pH}$ se afastou desse valor.

Knorr (1980) verificou que a solubilidade de concentrados protéicos de batata aumentou nos produtos menos desnaturados durante o processamento. Estes teriam maior probabilidade de serem funcionalmente ativos em sistemas em que a solubilidade da proteína é condição essencial, como em produtos onde há emulsificação envolvida no processo. Entretanto, segundo Kolar et al., (1985) a baixa solubilidade pode ser desejável em aplicações com altos níveis de proteína ou quando baixa emulsificação ou interações proteína-proteina são necessárias.

Para Cheftel et al. (1989) é incorreto afirmar que as proteinas sempre devem ter elevada solubilidade inicial para que as outras propriedades funcionais sejam boas 
Diz-se que a absorção de água de um ingrediente protéico pode às vezes melhorar com uma desnaturação e insolubilização prévia.

\subsubsection{Absorção espontânea de água}

Segundo Bartholomai \& Pilosof (1985), essa propriedade das proteínas tem grande importância nas etapas que envolvem a incorporação de água a ingredientes protéicos secos, como na preparação de massa ou na preparação de produtos cárneos. Ela relaciona-se com a quantidade de água que permanece na proteína ou alimento protéico após exposição a um excesso de água e aplicação de uma força de centrifugação ou pressão (Sgarbieri, 1996).

Os fatores que afetam a capacidade de absorção de água são os que afetam as interações água-proteina, especialmente o número e natureza dos sítios ativos da ligação da molécula de proteína, conformação, estrutura e demais características do meio em que se encontra, tais como o $\mathrm{pH}$, salinidade, temperatura, etc.

Os efeitos do pH e da temperatura na absorção de água, na maior parte dos resultados obtidos por Hutton \& Campbell (1977) mostraram a mesma tendência da verificada na solubilidade. Esses resultados sugeriram que a solubilidade e a absorção de água podem estar relacionadas até o ponto de máxima hidratação, a partir do qual a solubilidade continua a aumentar, mas a absorção de água não. 


\subsubsection{Propriedades de superfície}

\subsubsection{Emulsificação}

Emulsificação é a medida da capacidade da proteína de revestir gotículas de óleo na formação de uma emulsão (Kolar et al., 1985).

O estudo desta propriedade funcional geralmente se relaciona com a aplicação de concentrados e isolados protéicos em salsichas ou embutidos cárneos. Nesse tipo de emulsões, a fase contínua é a água e o agente emulsificante são as proteinas solúveis da carne.

As proteinas, por terem propriedades hidrofilicas e hidrofóbicas, são agentes de superficie ativos, apresentando boa propriedade de emulsificação em alimentos (Kinsella et al., 1985).

A superficie ativa das proteínas se coloca junto à interface lipídeo-água, reduzindo a tensão superficial e facilitando a formação de emulsões. A fração solúvel das proteínas é a que desempenha o papel mais ativo na emulsificação. Para tanto, a capacidade de emulsificação depende dos outros fatores como pH e força iônica (Kinsella et al., 1985).

Comparações confiáveis da capacidade de emulsificação de proteína podem ser feitas somente quando a velocidade de agitação, a concentração de proteína, a taxa de adição do óleo e o pH para a máxima dissolução da proteína forem otimizados para cada amostra de proteína. 


\subsubsection{Capacidade de formação de espuma}

Essa propriedade é de interesse prático quando se pensa em substitutos da clara de ovo para sobremesas geladas, tortas e merengues (Bartholomai \& Pilosof, 1985).

A espuma é composta por bolhas de gás encapsuladas em um fino filme hidratado com um agente surfactante. $\mathrm{O}$ agente surfactante diminui a tensão superficial do liquido, facilitando a sua deformação e a grande expansão observada em sua área superficial contribui, diminuindo também a tensão interfacial (Kinsella et al., 1985)

A superficie ativa das proteinas permite que elas sejam utilizadas para a preparação de espumas. A estabilidade das espumas depende da interação entre vários fatores como tensão superficial, viscosidade, área superficial e temperatura. Em muitos casos, o gás é o ar (eventualmente gás carbônico) e a fase contínua uma solução ou suspensão aquosa que contém as proteínas (Cheftel et al., 1989).

Os estudos com proteínas de diferentes origens demonstraram que o papel que as proteínas desempenham nos alimentos espumantes está muito relacionado com a sua solubilidade e é influenciado pelo $\mathrm{pH}$, sais e pelo tratamento térmico recebido durante o processo de extração. A capacidade de uma proteína formar espuma refere-se à expansão de volume da dispersão protéica com a incorporação de ar por batimento, agitação ou aeração. O que se procura medir, normalmente, é a expansão de volume da suspensão de proteína, imediatamente após batimento ou aeração, representada pelo volume de espuma formada. A estabilidade de espuma diz respeito à retenção do volume máximo de espuma formado em função do tempo de repouso (Sgarbieri, 1996). 


\subsubsection{Propriedades reológicas}

O estudo das características reológicas das soluções e suspensões de proteína fornece informações básicas da sua capacidade de participação na estrutura dos alimentos. A viscosidade das suspensões de proteínas depende de alguma forma da sua solubilidade, sendo influenciada pelo $\mathrm{pH}$, força iônica e tratamento térmico. A viscosidade é dependente do grau de hidratação e agregação das proteínas. As proteínas de soja altamente dissociadas tem baixa viscosidade (Kolar et al., 1985). 


\section{MATERIAL E MÉTODOS}

\subsection{Material}

\subsubsection{Matéria-prima}

A torta da castanha-do-pará utilizada no trabalho, era o resíduo resultante da extração de óleo por prensagem de castanhas-do-pará recebidas da Cooperativa Agroextrativista de Xapuri Ltda - Xapuri/Acre, inteiras e descascadas que foram préaquecidas e prensadas em mini prensa ENG-50 da ENGEO no Instituto de Tecnologia de Alimentos - Ital/Campinas, para obtenção de óleo bruto, objeto de estudo de outro trabalho conduzido pelo Laboratório de Óleos e Gorduras do Departamento de Ciência e Tecnologia de Alimentos/ESALQ -USP .

A torta da castanha-do-pará foi armazenada à temperatura de refrigeração, por 6 meses, até o início dos ensaios.

\subsubsection{Torta desengordurada de castanha-do-pará}

A torta desengordurada de castanha-do-pará utilizada para a produção do concentrado e isolado protéico foi obtida conforme descrito no ítem 4.2.1.4. 
4.1.3. Concentrado protéico de torta desengordurada de castanha-dopará - PROPARÁ

O concentrado protéico de torta desengordurada de castanha-do-pará, PROPARÁ, cujas propriedades foram analisadas, foi obtido conforme descrito no item 4.2.2.

4.1.4. Isolado protéico de torta desengordurada de castanha-do-pará ISPARÁ

$\mathrm{O}$ isolado protéico de torta desengordurada de castanha-do-pará, ISPARÁ, cujas propriedades foram analisadas, foi obtido conforme descrito no ítem 4.2.3.

\subsection{Métodos}

4.2.1. Determinação do processo mais adequado para obtenção do concentrado protéico de torta de castanha-do-pará(CPTCP) e do isolado protéico de torta de castanha-do-pará (IPTCP)

O objetivo foi avaliar a possibilidade de produção de concentrado protéico com o uso da torta de castanha-do-pará (TCP) integral, testando-se as principais variáveis que se relacionam com a eficiência do processo de obtenção do concentrado e 
isolado protéico tais como uso do ácido clorídrico e etanol na precipitação da proteína, a proporção matéria-prima/solução precipitante, $\mathrm{pH}$, modo de separação do precipitado/material solúvel e tempo de agitação.

E com a constatação da influência da quantidade de óleo sobre a concentração de proteína nos produtos finais, submeteu-se a torta de castanha-do-pará à extração do óleo com diferentes tipos de solvente. Neste caso foi escolhido o processo mais econômico, prático e mais eficiente na extração do óleo. A avaliação da eficiência dos ensaios foi feita pela determinação da quantidade de proteina de cada produto obtido.

\subsubsection{Ensaio 1 - Obtenção do Concentrado}

Com o objetivo de avaliar a eficiência da proporção matéria-prima/sol. $\mathrm{HCl}$ e o modo de separação do precipitado/material solúvel na produção de concentrado protéico de torta de castanha-do-pará as seguintes variáveis foram avaliadas:

I) precipitação da proteína a $\mathrm{pH} 3,5$ na proporção de 1 parte de TCP para 10 partes de solução de $\mathrm{HCl}$.

II) precipitação da proteina a pH 3,5 na proporção de 1 parte de TCP para 15 partes de solução de $\mathrm{HCl}$.

A) Separação do precipitado/material solúvel através de centrifugação a 1200 $x$ G durante 20 minutos.

B) Separação do precipitado/material solúvel através de filtração a vácuo. 
A Figura 1 apresenta a sequência das etapas do processamento

\section{TORTA DE CASTANHA-DO-PARÁ (TCP) \\ $\downarrow$ PRECIPITAÇÃO PROTÉICA}

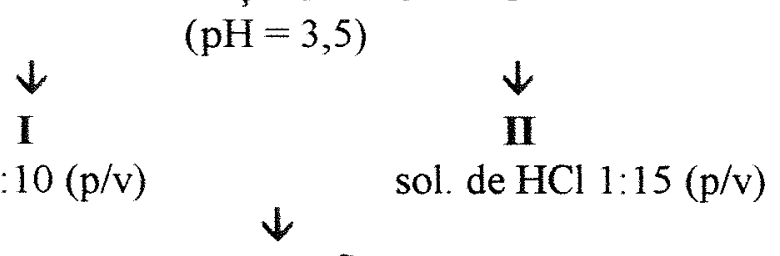

\section{AGITAÇÃo}

(1 hora, temperatura ambiente, agitação magnética)

$$
\downarrow
$$

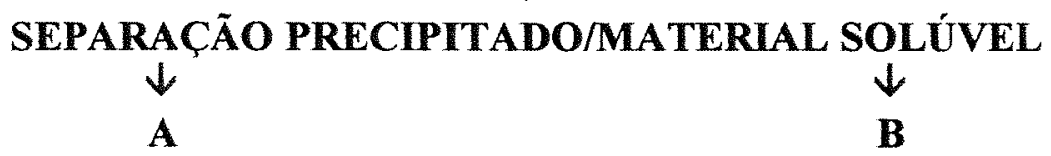

Centrifugação (1200 x G - 20 minutos)

Filtração a vácuo

\section{SECAGEM}

(estufa de circulação forçada de ar a $40^{\circ} \mathrm{C}$ )

$\downarrow$

TRITURAÇÃo

(em processador)

$\downarrow$

CONCENTRADO PROTÉICO DE TCP

Figura 1 - Obtenção do concentrado protéico de TCP com variação da proporção matériaprima/sol. de $\mathrm{HCl}$ de precipitação da proteína e do modo separação do precipitado/material solúvel, utilizando a torta integral.

\subsubsection{Ensaio 2 - Obtenção do Concentrado}

Neste ensaio para a obtenção de concentrado protéico de torta de castanhado-pará, avaliou-se a eficiência do etanol em várias concentrações e a concentração de melhor resultado foi aplicada com aquecimento a $70^{\circ} \mathrm{C}$ em banho maria (Figura 2): 


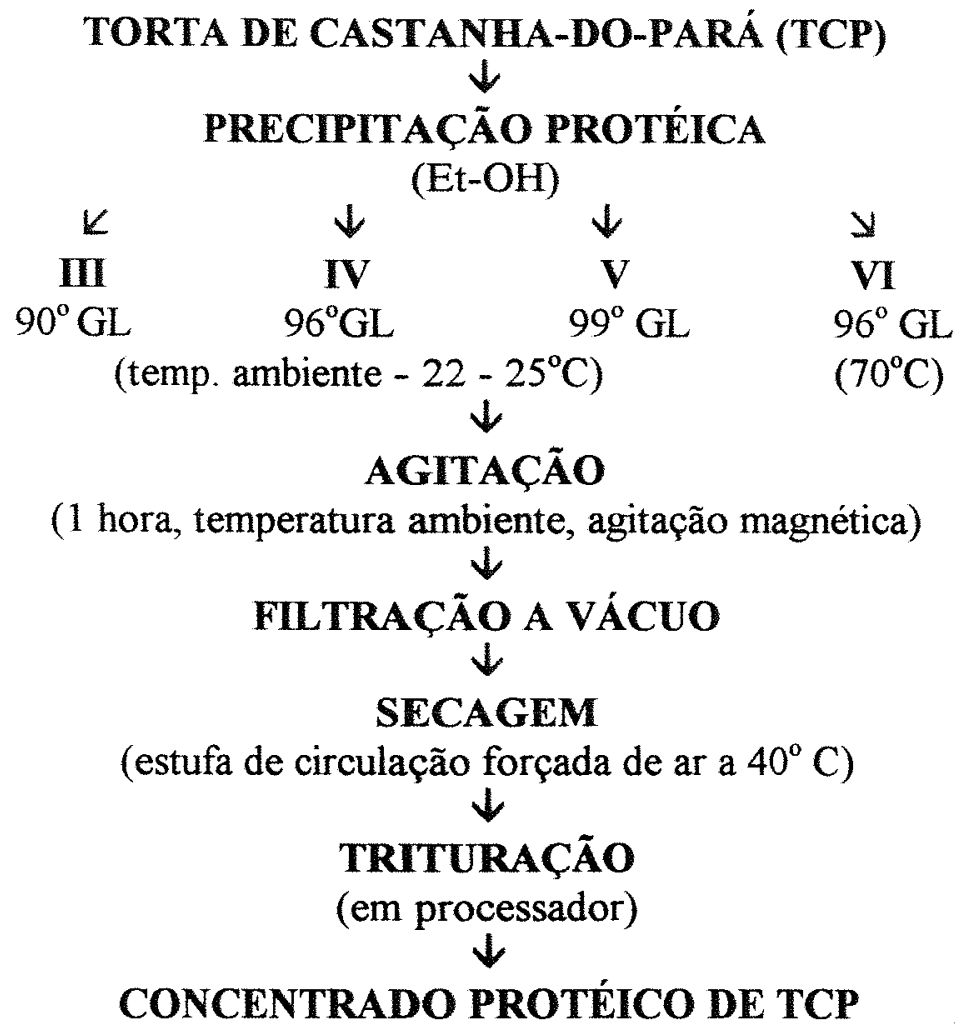

Figura 2 - Obtenção do concentrado protéico de TCP, utilizando etanol (Et-OH) como agente precipitador de proteína, a partir da torta integral.

I) precipitação protéica com Et-OH $90^{\circ} \mathrm{GL}$ na proporção de 1:15 - p/v

II) precipitação protéica com Et-OH $96^{\circ} \mathrm{GL}(1: 15-\mathrm{p} / \mathrm{v})$

III) precipitação protéica com Et-OH $99^{\circ} \mathrm{GL}(1: 15$ - p/v)

IV) precipitação protéica com Et-OH $96^{\circ} \mathrm{GL}\left(1: 15\right.$ - p/v) a $70^{\circ} \mathrm{C}$.

As concentrações utilizadas foram escolhidas com base nos trabalhos de Regitano-d'Arce et al. (1994), Silva \& Turatti (1991) e Campbell et al. (1985). 


\subsubsection{Ensaio 3 - Obtenção do Isolado}

A influência do $\mathrm{pH}$ de precipitação das proteínas após extração com solução de $\mathrm{NaOH}$ na produção de isolado protéico de torta de castanha-do-pará foi avaliada. A precipitação protéica foi feita pela adição de solucão de $\mathrm{HCl}$ até que se atingissem os valores desejados de $\mathrm{pH}$ (Figura 3).

\section{TORTA DE CASTANHA-DO-PARÁ (TCP) \\ $\downarrow$ \\ EXTRAÇÃo PROTÉICA(pH $10 \mathrm{c} / \mathrm{sol}$. $\mathrm{NaOH} 1: 15$ - p/v) $\downarrow$ \\ AGITAÇ̃̃o \\ (1 hora, temperatura ambiente, agitação magnética) \\ $\downarrow$ \\ FILTRAÇÃo A VÁCUO \\ $\downarrow$}

PRECIPITAÇÃO PROTÉICA

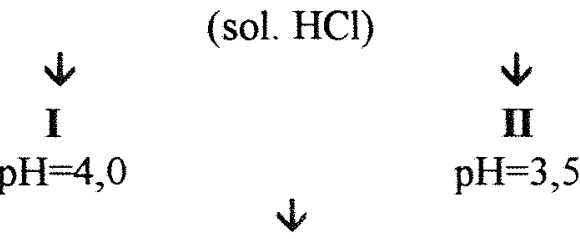

AGITAÇão

(1 hora, temp. ambiente, agitação magnética)

\section{FILTRAÇ̃̃o A VÁCUO \\ $\downarrow$ \\ SECAGEM}

(estufa de circulação forçada de ar a $40^{\circ} \mathrm{C}$ )

$\downarrow$

TRITURAÇÃo

(em processador)

$\downarrow$

ISOLADO PROTÉICO DE TCP

Figura 3 - Obtenção do isolado protéico da TCP com variação do $\mathrm{pH}$ de precipitacão da proteina, utilizando a torta integral. 


\subsubsection{Extração do óleo da torta de castanha-do-pará.}

Com o objetivo de obter uma matéria-prima com maior teor de proteina, submeteu-se a torta à extração, utilizando-se os seguintes solventes:

I - Et-OH a $99^{\circ} \mathrm{GL}(1: 5 \mathrm{p} / \mathrm{v})$ a $70^{\circ} \mathrm{C}$, em banho-maria, com agitação (agitador magnético) durante 45 minutos, seguida de filtração a vácuo e secagem em estufa de circulação de ar forçado por 2 horas a $40^{\circ} \mathrm{C}$.

II- Et-OH a $99^{\circ} \mathrm{GL}$ a $70^{\circ} \mathrm{C}(1: 2,5 \mathrm{p} / \mathrm{v})$, em banho-maria, com agitação (agitador magnético) durante 45 minutos, seguida de filtração a vácuo, por 2 vezes, secagem em estufa de circulação de ar forçado por 2 horas a $40^{\circ} \mathrm{C}$.

III - Hexano, na proporção de 1 parte de torta de castanha-do-pará (TCP) para 10 partes de solvente, à temperatura ambiente $\left(22-25^{\circ} \mathrm{C}\right)$, em homogeneizador (liqüidificador doméstico, marca Arno, modelo MMA, velocidade 3). Adicionou-se ao total de TCP a metade do solvente $(1: 5-\mathrm{p} / \mathrm{v})$ a ser usado em toda a extração, para homogeneização à velocidade média, por 3 minutos. Filtrou-se a vácuo para a separação da miscela do material semi-desengordurado. Após a filtração adicionou-se o restante do solvente ao material semi-desengordurado e extraiu-se por mais 3 minutos, repetindo a filtração a vácuo e o material desengordurado foi dessolventizado em estufa com circulação de ar forçada a $40^{\circ} \mathrm{C}$ durante 2 horas.

A Figura 4 resume as etapas do processo de extração do óleo com hexano e etanol. 


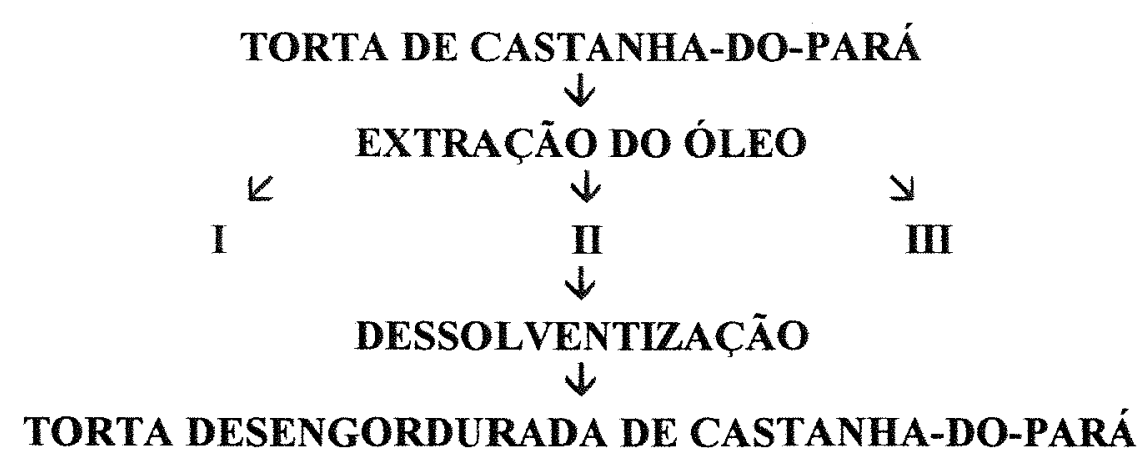

Figura 4 - Obtenção da torta desengordurada de castanha-do-pará

\subsubsection{Ensaio 4 - Obtenção do Concentrado}

Os concentrados deste ensaio foram conseguidos através de precipitação com $\mathrm{HCl}$ 1:15 (p/v) a pH 3,5 e variação do tempo de agitação (Figura 5).

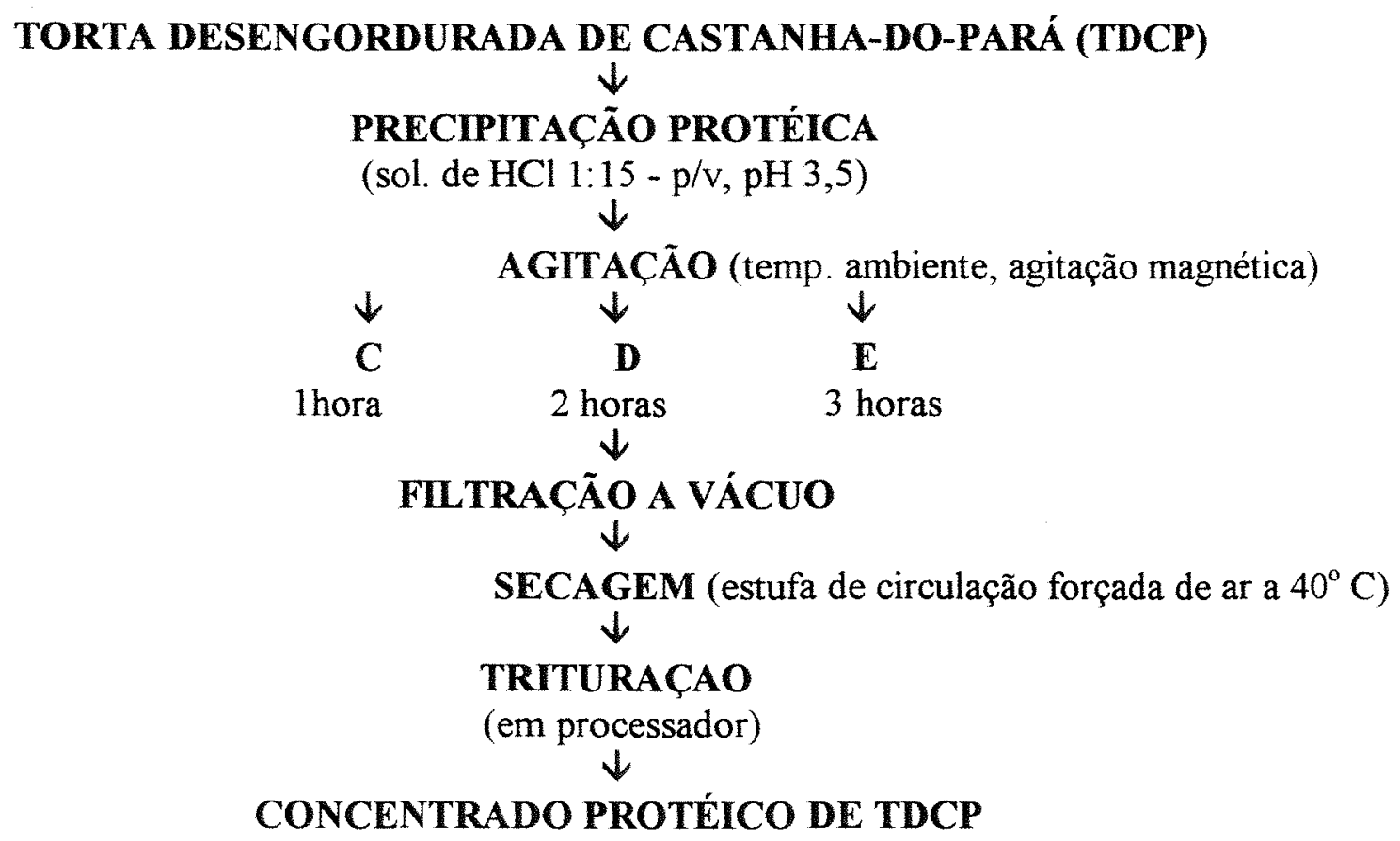

Figura 5 - Obtenção do concentrado protéico de TDCP com variação do tempo de agitação, utilizando a torta desengordurada de castanha-do-pará. 


\subsubsection{6 - Ensaio 5 - Obtenção do Isolado}

Uma vez que tanto em pH 9 como em pH 10 tem-se solubilidade da proteína muito próxima procurou-se fazer a extração protéica com o menor custo.

Estudaram-se também as variáveis de tempo de agitação tanto da proteina solúvel como da proteína precipitada. (Figura 6)

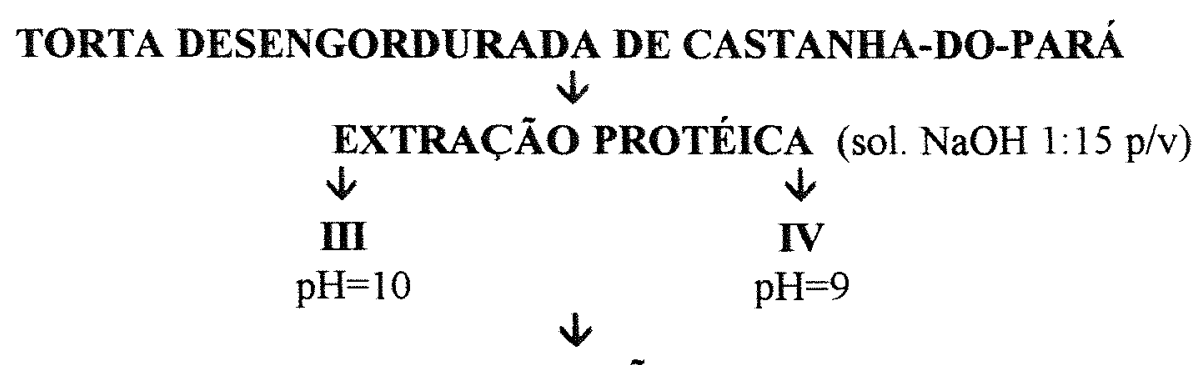

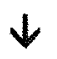

A

1 hora

AGITAÇÃO(temp. ambiente, agitação magnética)

B

2 horas

FILTRAÇÃo A VÁCUO

$\downarrow$

PRECIPITAÇÃo PROTÉICA (em $\mathrm{pH}=4 \mathrm{com}$ sol. $\mathrm{HCl}$ ) $\downarrow$

AGITAÇÃO(temp. ambiente, agitação magnética)

$\downarrow$

C

$\downarrow$

D

1 hora

2 horas

FILTRAÇÃo A VÁCUO

$\downarrow$

SECAGEM

$\downarrow$

TRITURAÇÃO

$\downarrow$

ISOLADO PROTÉICO DE TDCP

Figura 6 - Obtenção de isolado protéico de TDCP com variação do tempo de agitação e do pH de extração protéica, com a torta desengordurada de castanha-do-pará. 


\subsubsection{Obtenção do concentrado protéico de torta desengordurada de castanha-do-pará (PROPARÁ).}

\subsubsection{Precipitação das proteínas}

A torta desengordurada foi homogeneizada com um solução aquosa de ácido clorídrico na proporção de $1: 15(\mathrm{p} / \mathrm{v})$, em agitador magnético, durante 3 horas, à temperatura ambiente $\left(22-25^{\circ} \mathrm{C}\right)$, em $\mathrm{pH}$ sempre ao redor de 3,5 . (Figura 7 )

\subsubsection{Separação dos constituintes solúveis}

A separação dos constituintes solúveis, que se desejavam eliminar, foi feita através de filtração a vácuo.

\subsubsection{Secagem}

O precipitado protéico foi seco, em sua forma isoelétrica, em estufa com circulação forçada de ar a $40^{\circ} \mathrm{C}$, durante 3 horas.

\subsubsection{Trituração}

A trituração foi feita em multi-processador Arno, na função processador, até granulometria inferior à malha 100 da peneira da séries 'US Standard". 


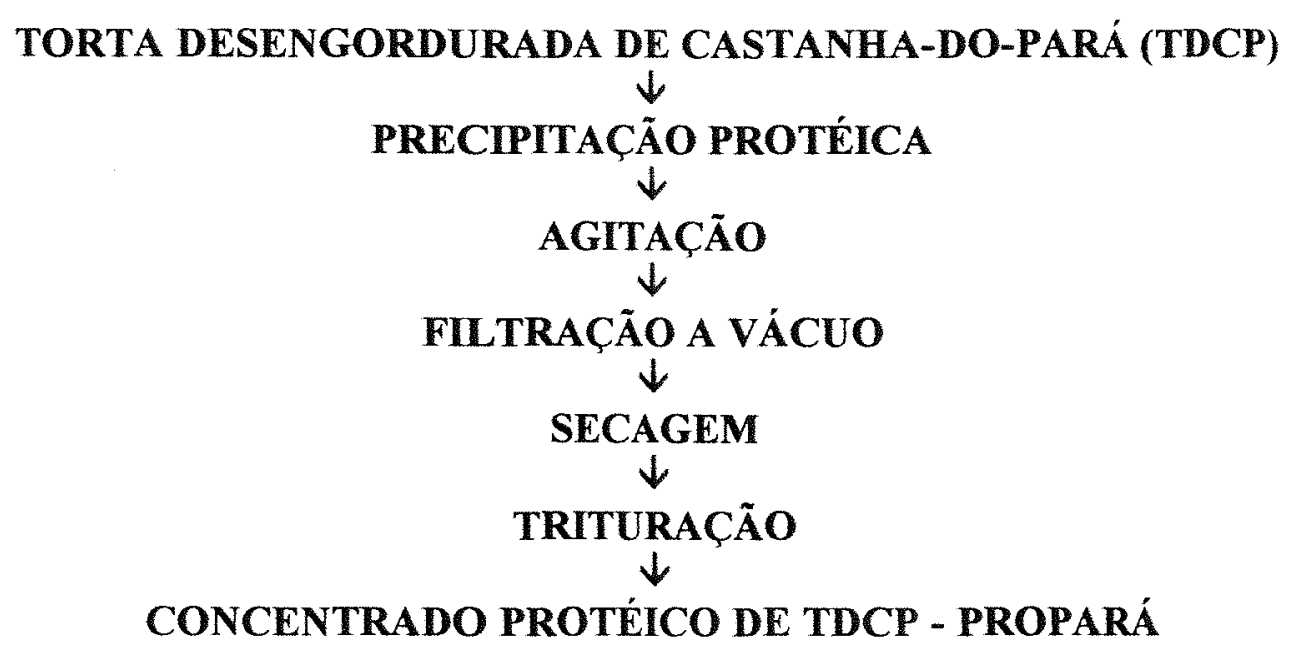

Figura 7 - Processo de obtenção do PROPARÁ

4.2.3. Obtenção do isolado protéico de torta desengordurada de castanha-do-pará (ISPARÁ).

\subsubsection{Extração das proteínas}

A torta desengordurada foi misturada com solução aquosa de hidróxido de sódio na proporção de 1:15 (p/v). Esta mistura foi submetida à agitação, em agitador magnético, por 2 horas, à temperatura ambiente $\left(22-25^{\circ} \mathrm{C}\right)$, mantendo-se o $\mathrm{pH}$ sempre ao redor de 9 . 


\subsubsection{Separação dos resíduos insolúveis}

A separação dos resíduos insolúveis dessa suspensão foi realizada por filtração a vácuo.

\subsubsection{Precipitação do extrato de proteínas solúveis}

O extrato que continha as proteinas solubilizadas e demais componentes solúveis foi acidificado até $\mathrm{pH}$ próximo de 4 , com ácido clorídrico, à temperatura ambiente $\left(22-25^{\circ}\right)$, sob agitação durante 2 horas (Figura 8).

\subsubsection{Separação do precipitado dos constituintes solúveis}

A separação do precipitado dos constituintes solúveis foi feita por filtração a vácuo.

\subsubsection{Secagem}

O precipitado protéico foi seco, na sua forma isoelétrica, em estufa com circulação forçada de ar a $40^{\circ} \mathrm{C}$, durante 4 horas. 


\subsubsection{Trituração}

A trituração foi feita em multi-processador Árno, na função processador, de modo a obter granulometria inferior a malha 100 da peneira da série"US Standard".

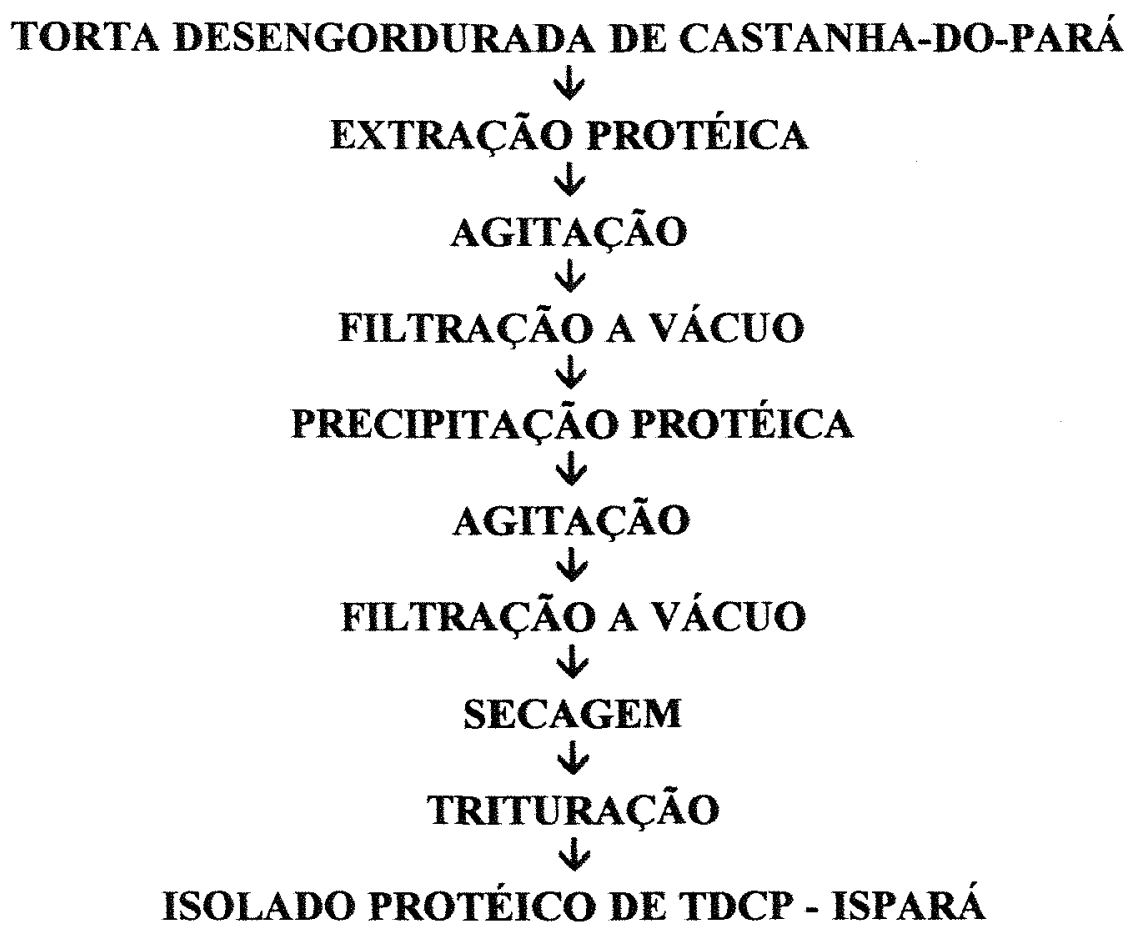

Figura 8 -Processo de obtenção do ISPARÁ.

\subsubsection{Análises químicas de caracterização}

As análises citadas a seguir foram realizadas na matéria-prima (torta desengordurada) e nos produtos obtidos (PROPARÁ e ISPARÁ).

O perfil aminoacídico foi determinado somente na torta desengordurada. 


\subsubsection{Teor de umidade}

Determinada segundo método $n^{\circ} 925.40$ da AOAC (1995).

\subsubsection{Teor de proteína bruta}

Determinado pelo método semi-micro-Kjeldahl, usando o fator de conversão

5,46, segundo método $n^{\circ} 950.48$ AOAC (1995).

\subsubsection{Teor de lipídeos totais}

Determinado pelo método gravimétrico, usando extrator de Soxhlet, segundo AOCS, método Ac 3-44 (1991).

\subsubsection{Teor de cinza}

Determinado pelo método 4.8 - Normas Analíticas do Instituto Adolfo Lutz (1985)

\subsubsection{Teor de fibras totais}

Estas análises foram realizadas pelo Departamento de Zootecnia, Laboratório de Bromatologia, da ESALQ/USP, através do método da AOAC - 962-09 (1995).

\subsubsection{Teor de carboidratos}

Calculado por diferença (100 - somatória dos resultado 4.2.4.2. a 4.2.4.5. acima) 


\subsubsection{Perfil aminoacídico}

A análise do teor de aminoácidos foi realizada pela Faculdade de Ciências Farmacêuticas/USP, Departamento de Alimentos e Nutrição Experimental - Laboratório de Análise de Alimentos, por cromatografia de troca iônica em analisador automático de aminoácidos da marca Beckman, modelo 7300 , que quantifica os aminoácidos por área dos picos com mistura padrão de aminoácidos em integrador Hewlett-Packard.

\subsubsection{Análise estatística}

A análise do desvio padrão foi feita seguindo a formula abaixo e a avaliação da diferença mínima significativa foi feita através do Teste de Turkey, de acordo com Gomes (1990), em software EXCEL versão 5.0 WINDOWS 95.

Desvio padrão $=\sqrt{ } \underline{\mathrm{SQN}}$

$\mathrm{n}$

onde $\mathrm{SQN}=$ soma dos quadrados do desvio $\mathrm{n}=$ número de repetições

\subsubsection{Propriedades funcionais}

Para a caracterização tecnológica do concentrado e isolado protéico de torta desengordurada da castanha-do-pará foram avaliadas as seguintes propriedades funcionais: 


\subsubsection{Solubilidade}

Foi disperso $1 \mathrm{~g}$ do material em estudo em $50 \mathrm{ml}$ de água destilada com $\mathrm{pH}$ ajustado de 2 a 12, com $\mathrm{HCl}$ ou $\mathrm{NaOH}$ diluídos. Após um periodo de 10 minutos, o $\mathrm{pH}$ foi reajustado. A dispersão foi mantida sob agitação por 1 hora e filtrada. Do sobrenadante foram retiradas alíquotas para a determinação de $\mathrm{N}$ total pelo método de semi-microKjeldahl conforme AOAC (1995). O método utilizado foi o adaptado de Chen $\&$ Morr (1985).

$O$ índice de solubilidade de nitrogênio foi calculado da seguinte forma:

ISN $\%=(\%$ nitrogênio solúvel em sol. aquosa $/ \%$ nitrogênio total da amostra $) \times 100$

\subsubsection{Capacidade de absorção de água}

Uma amostra de $0,5 \mathrm{~g}$ do material estudado foi homogeneizada em $5 \mathrm{ml}$ de água destilada, em tubo de centrífuga graduado, por 1 minuto, deixada em repouso por 30 minutos à temperatura ambiente $\left(22-25^{\circ} \mathrm{C}\right)$, para em seguida, ser centrifugada por 30 minutos a $2600 \mathrm{rpm}(1200 \times \mathrm{G})$. A água retida após a centrifugação foi considerada como água absorvida (Sgarbieri, 1996; Sosulski et al., 1976).

O sedimento no tubo da centrifuga, após separação do sobrenadante foi pesado e a capacidade de absorção de água (CAA) calculada pela expressão:

$\% \mathrm{CAA}=[$ Peso do sedimento $(\mathrm{g}) /$ Peso do material utilizado $(\mathrm{g})] \times 100$ 


\subsubsection{Capacidade de absorção de óleo}

Uma amostra de $0,5 \mathrm{~g}$ do material estudado foi homogeneizada com $3 \mathrm{~g}$ de óleo de milho refinado em tubo de centrifuga graduado por 1 minuto, deixada em repouso por 30 minutos à temperatura ambiente $\left(22-25^{\circ} \mathrm{C}\right)$ e, em seguida, centrifugada durante 30 minutos a 1200 x G (Sgarbieri, 1996; Lin \& Humbert, 1974).

O sedimento no tubo da centrífuga, após separação do sobrenadante foi pesado e a capacidade de absorção de óleo $(\mathrm{CAO})$ calculado pela expressão:

$\% \mathrm{CAO}=[$ Peso do sedimento $(\mathrm{g}) /$ Peso do material utilizado $(\mathrm{g})] \times 100$

\subsubsection{Capacidade de formação de espuma}

A capacidade de formar espuma foi determinada por uma combinação dos métodos de Dipak \& Kumar (1986) e Phillips et al. (1987). Cinco gramas de amostra foram batidos com $100 \mathrm{ml}$ de água destilada durante 5 minutos, usando-se a máxima rotação em homogeneizador de haste e hélice na base, marca Arno, modelo MMA. O volume aumentado pelo batimento foi medido em uma proveta de $500 \mathrm{ml}$.

A porcentagem do aumento de volume foi calculada pela expresssão:

Aumento de volume $\%=(\mathrm{B}-\mathrm{A}) / \mathrm{A} \times 100$

onde: $\mathrm{A}=$ volume antes da agitação $(\mathrm{ml})$

$\mathrm{B}=$ volume após batimento $(\mathrm{ml})$ 
O estudo da estabilidade da espuma foi feito, deixando-a em repouso à temperatura ambiente $\left(22-25^{\circ} \mathrm{C}\right)$ e fazendo-se as leituras do volume total após intervalos de $1,5,10,30$ e 60 minutos. 


\section{RESULTADOS E DISCUSSÃO}

\subsection{Torta integral}

\subsubsection{Composição química}

A torta da castanha-do-pará, apesar de ser um resíduo da extração de óleo contém grande quantidade de lipídeos $(42,21 \%)$, muito próxima da quantidade encontrada por Costa \& Mota (1942), de $38,50 \%$. O teor de proteína de $29,42 \%$ $(\% \mathrm{~N} \times 5,46)$ coincide com os encontrados na literatura (Tabela 3$)$.

Tabela 3 - Composição química da torta integral *

\begin{tabular}{c|c|c|c|c}
\hline Compontentes & Proteina bruta $(\% \mathrm{~N} \times 5,46)$ & Óleo & Carboidratos & Cinza \\
\hline Teor em $\%$ & $29,42( \pm 0.068)$ & $42,21( \pm 0.045)$ & 20,55 & 8,19 \\
\hline
\end{tabular}

*resultados das análises em matéria seca com média de três repetições ( \pm desvio padrão)

teor de umidade da torta $=5 \%( \pm 0,0493)$ 


\subsubsection{Produtos obtidos com a torta integral através do estudo das variáveis}

\subsubsection{Ensaio 1 - Obtenção de Concentrado}

Verificou-se a influência da proporção de matéria-prima/solução de $\mathrm{HCl}$ e do modo de separação precipitado/material solúvel.

A precipitação proteica foi alcançada com solução aquosa ácida de $\mathrm{HCl}$ a pH 3,5, porque a proteina da TCP tem seu ponto isoelétrico entre os $\mathrm{pH}^{\mathrm{s}} 3$ - 4 consequentemente as proteinas estão insolúveis e ocorre a precipitação.

O melhor rendimento com relação à precipitação de proteínas foi obtido utilizando-se a relação de 1:15 (p/v). Apesar da pouca diferença comparando com a precipitação protéica conseguida com a relação $1: 10(\mathrm{p} / \mathrm{v})$, optou-se por utilizar a relação de $1: 15(\mathrm{p} / \mathrm{v})$ pela maior facilidade de trabalho, diminuindo-se as perdas durante as transferências do material de um recipiente para outro.

Com relação à separação do material solúvel/precipitado, foi na filtração a vácuo que se obteve um rendimento maior pelo mesmo motivo alcançado anteriormente $\mathrm{e}$ pela praticidade e economia.

Na Tabela 4 confirmou-se que o concentrado obtido com a proporção de matéria-prima/solução $\mathrm{HCl}$ 1:15 (p/v) e filtração a vácuo foi o melhor. 
Tabela 4 - Caracterização dos concentrados protéicos de TCP obtidos através da variação do $\mathrm{pH}$ de precipitação da proteina e do modo de separação do precipitado/material solúvel, utilizando a torta integral. (ENSAIO 1) *

\begin{tabular}{c|c|c}
\hline tratamentos & proteina $(\% \mathrm{~N} \times 5,46)$ & $\%$ óleo \\
\hline IA & $33,27( \pm 0,0435)$ & $40,10( \pm 0,0264)$ \\
IB & $33,60( \pm 0,0721)$ & $40,85( \pm 0,0608)$ \\
IIA & $34,00( \pm 0,0404)$ & $40,00( \pm 0,0866)$ \\
IIB & $34,17( \pm 0,01)$ & $39,80( \pm 0,0152)$ \\
\hline
\end{tabular}

IA - sol. HCl $1: 10 \mathrm{p} / \mathrm{v}+$ centrifugação $1200 \times \mathrm{G}-20$ minutos

IB - sol HCl $1: 15 \mathrm{p} / \mathrm{v}+$ centrifugação $12000 \times \mathrm{G}-20$ minutos

ПIA - sol $\mathrm{HCl} 1: 10 \mathrm{p} / \mathrm{v}+$ filtração a vácuo

IIB - sol $\mathrm{HCl} 1: 15 \mathrm{p} / \mathrm{v}+$ filtração a vácuo

*resultados das análises em matéria seca com média de três repetições ( \pm desvio padrão)

\subsubsection{Ensaio 2 - Obtenção do Concentrado}

Neste ensaio utilizou-se uma solução hidroalcoólica de etanol em várias concentrações como agente precipitante. $\mathrm{O}$ etanol desnatura as proteinas e reduz a concentração de outros componentes que são solúveis (Campbell et al., 1985).

O óleo é um dos principais componentes que podem ter seu teor reduzido com o uso do solvente etanol (Rossi et al., 1980).

O emprego de soluções de diferentes concentrações hidroalcoólicas de etanol utilizadas neste Ensaio teve o objetivo de precipitar as proteinas e reduzir o teor de lipídeos $(42,21 \%)$ da torta de castanha-do-pará utilizada como matéria-prima. 
As concentrações de 90,96 e $99^{\circ} \mathrm{GL}$, à temperatura ambiente $\left(22-25^{\circ} \mathrm{C}\right)$ utilizadas para a obtenção de concentrados protéicos não foram eficientes. $O$ alto conteúdo de óleo prejudicou a concentração de proteina.

No tratamento VI, desse ensaio, observou-se uma redução mais expressiva, em relação aos outros tratamentos, no teor de lipídeos. Essa redução talvez tenha sido devido ao aquecimento $\left(70^{\circ} \mathrm{C}\right)$ durante o processo de precipitação protéica (Tabela 5).

Isto confirma observações de Silva \& Turatti (1991) de que a solubilidade dos óleos nas soluções de etanol pode variar muito em função da temperatura e da concentração do etanol, da composição do óleo e da metodologia do estudo.

A porcentagem de proteína que apresentou o concentrado obtido através do tratamento VI foi muito próximo à dos concentrados do Ensaio 1, apesar disso, não se recomenda o tratamento VI do Ensaio 2 devido ao alto custo comparado com a precipitação feita com o ácido e também pelo aumento de risco de acidentes.

Tabela 5 - Caracterização dos concentrados protéicos de TCP com variação do agente precipitante da proteina, utilizando a torta integral. (ENSAIO 2) *

\begin{tabular}{c|c|c}
\hline tratamentos & proteína $(\% \mathrm{~N} \times 5,46)$ & $\%$ óleo \\
\hline III & $31,05( \pm 0,0173)$ & $40,00( \pm 0,0866)$ \\
IV & $32,18( \pm 0,01)$ & $39,70( \pm 0,0115)$ \\
V & $32,16( \pm 0,01)$ & $39,50( \pm 0,01)$ \\
VI & $33,00( \pm 0,0121)$ & $37,00( \pm 0,063)$ \\
\hline III $-90^{\circ} \mathrm{GL}$ & \\
IV $-96^{\circ} \mathrm{GL}$ & \\
$\mathrm{V}-99^{\circ} \mathrm{GL}$ & \\
VI $-96^{\circ} \mathrm{GL}$ a $70^{\circ} \mathrm{C}$ & \\
*resultados das análises em matéria seca com média de três repetições $( \pm$ desvio padrão $)$
\end{tabular}




\subsubsection{Ensaio 3 - Obtenção de Isolado}

As variáveis empregadas nos processos de obtenção dos concentrados (Ensaios 1 e 2), que apresentaram os melhores resultados foram adotadas neste Ensaio para a obtenção dos isolados.

Neste Ensaio estudou-se o pH de precipitação da proteina.

$\mathrm{O}$ pH 4 forneceu o melhor rendimento (Tabela 6).

A extração protéica foi feita com $\mathrm{NaOH}$, um álcali que proporciona a condição alcalina necessária para a boa extração, conforme Betschart \& Kinsella (1973).

Tabela 6 - Caracterização dos isolados protéicos de TCP obtidos através de variação do pH de precipitação da proteína, utilizando a torta integral. (ENSAIO 3) *

\begin{tabular}{c|c|c}
\hline tratamentos & proteína $(\% \mathrm{~N} \times 5,46)$ & $\%$ óleo \\
\hline I & $63,42( \pm 0,021)$ & $25,00( \pm 0,01)$ \\
II & $52,62( \pm 0,012)$ & $25,40( \pm 0,01)$ \\
\hline
\end{tabular}

$\mathrm{I}-\mathrm{pH}=4$

II - $\mathrm{pH}=3,5$

*resultados das análises em matéria seca com média de três repetições ( \pm desvio padrão)

\subsection{Torta desengordurada de castanha-do-pará (TDCP) - extração e perfil aminoacídico}

A extração de óleo da TCP teve como objetivo concentrar a proteína da matéria-prima, facilitando desse modo a obtenção de concentrado e isolado protéicos. 
O solvente hexano foi mais apropriado, porque além de ser um solvente com pouca habilidade de desnaturar proteinas, permite uma extração prática e rápida, a temperaturas moderadas. O etanol não foi tão eficiente extrator do óleo da torta como o hexano (Tabela 7).

A torta desengordurada de castanha-do-pará de menor teor de óleo escolhida como matéria-prima para os ensaios posteriores (4 e 5) foi triturada e apresentou-se na forma de um pó branco com granulometria inferior à malha 100 da peneira da série "US Standard"

Tabela 7 - Composição química da torta desengordurada de castanha-do-pará desengordurada, obtida através dos testes com os solventes hexano (à temp. ambiente), Et-OH $99^{\circ} \mathrm{GL}\left(\right.$ a $70^{\circ} \mathrm{C}$ ) e Et-OH $99^{\circ} \mathrm{GL}\left(\right.$ a $\left.70^{\circ} \mathrm{C}\right)$ em duas etapas. *

\begin{tabular}{c|c|c|c|c|c|c}
\hline testes & Umidade & $\begin{array}{c}\text { Proteina } \\
(\% \mathrm{~N} \times 5,46)\end{array}$ & Óleo & Cinza & Carboidrato & Fibra \\
\hline I & 4,00 & $41,38( \pm 0,031)$ & $4,83( \pm 0,011)$ & $14,00( \pm 0,0)$ & 39,79 & $* *$ \\
II & 5,70 & $44,00( \pm 0,012)$ & $2,84( \pm 0.013)$ & $15,10( \pm 0,012)$ & 38,06 & $* *$ \\
III & 4,50 & $47,64( \pm 0,013)$ & $1,18( \pm 0,013)$ & $13,05( \pm 0,011)$ & 32,71 & $5,52( \pm 0,0)$ \\
\hline
\end{tabular}

1- Et-OH a $99^{\circ} \mathrm{GL}$ a $70^{\circ} \mathrm{C}$

II - Et-OH a $99^{\circ} \mathrm{GL}$ a $70^{\circ} \mathrm{C}$ em duas etapas

III - Hexano à temperatura ambiente

*resultados das análises em matéria seca com média de trés repetições ( \pm desvio padrão)

** análise não realizada

Com relação ao perfil aminoacídico o que pôde-se verificar, através da Tabela 5, é que a torta desengordurada de castanha-do-pará, do teste III, manteve os altos teores de metionina, leucina, fenilalanina e valina encontrados por Ensminger et al., (1994) na castanha-do-pará "in natura" e por Antunes \& Markakis (1977) na torta desengordurada 
de castanha-do-pará. Pela comparação com o perfil aminoacídico da proteina padrão da FAO (1970) também podemos observar os altos teores dos aminoácidos sulfurados, metionina e cisteina, da torta desengordurada de castanha-do-pará.

Tabela 8. Composição aminoacídica da TCP desengordurada com hexano.

\begin{tabular}{llll}
\hline & \multicolumn{2}{c}{ TORTA } & OVO \\
aminoácidos & Teste III & $\begin{array}{c}\text { Antunes \& } \\
\text { Markakis }\end{array}$ & FAO \\
mg/100g de proteína & & $(1977)$ & \\
\hline Isoleucina & & 3664 & 6224 \\
Leucina & $3750( \pm 0,05)$ & 7232 & 8728 \\
Lisina & $8710( \pm 0,10)$ & 3296 & 6904 \\
Metionina & $3710( \pm 0,07)$ & 6176 & 3328 \\
Fenilalanina & $9550( \pm 0,08)$ & 4544 & 5672 \\
Treonina & $4920( \pm 0,08)$ & 5072 \\
Valina & $3160( \pm 0,04)$ & 2800 & 6776 \\
Cisteína & $5920( \pm 0,08)$ & 5552 & 2312 \\
\hline
\end{tabular}

\subsubsection{Ensaio 4 - Obtenção de Concentrado}

O tempo de agitação da matéria-prima/solução de $\mathrm{HCl}$ a pH 3,5 influenciou no rendimento protéico do concentrado. O maior tempo de agitação favoreceu uma concentração maior de proteína no produto final. 
Na Tabela 9 são apresentados os resultados conseguidos neste Ensaio. Constata-se que a maior concentração protéica foi conseguida com o maior tempo de agitação (3 horas).

Tabela 9 - Caracterização dos concentrados protéicos de TDCP com solvente hexano, variando o tempo de agitação. (ENSAIO 4) *

\begin{tabular}{|c|c|}
\hline tratamentos & proteina $(\% \mathrm{~N} \times 5,46)$ \\
\hline $\mathrm{C}$ & $47,00( \pm 0,01)$ \\
\hline $\mathrm{D}$ & $53,00( \pm 0,02)$ \\
\hline$E$ & $59,30( \pm 0.021)$ \\
\hline
\end{tabular}

\subsubsection{Ensaio 5 - Obtenção de Isolado}

A diferença obtida entre os pH's 9 e 10 de extração de proteina foi bastante pequena. Optou-se por utilizar o $\mathrm{pH} 9$, porque com a menor alcalinização, diminuia-se a possibilidade de ocorrência da reação de Maillard e também, por uma questão econômica, com menor gasto de álcali há menos gasto de ácido posterior.

O tempo de agitação influenciou tanto na agitação da proteína precipitada como da proteína solúvel. 
A Tabela 10 comprova que com o pH 9 e com os tempos de agitação do extrato protéico de 2 horas e da proteína precipitada de 2 horas também se conseguiu concentrar uma quantidade grande de proteína $81,88 \%(\% \mathrm{~N}$ x 5,46$)$.

Tabela 10 - Caracterização dos isolados protéicos de TDCP obtidos através da variação do pH de extração de proteina e do tempo de agitação. (ENSAIO 5) *

\begin{tabular}{c|c}
\hline tratamentos & proteína $(\% \mathrm{~N} \times 5,46)$ \\
\hline IIIAC & $74,81( \pm 0.010)$ \\
IIIBC & $76,00( \pm 0,010)$ \\
IIIBD & $80,50( \pm 0,010)$ \\
IVAC & $75,92( \pm 0,012)$ \\
IVBC & $72,03( \pm 0,0121)$ \\
IVBD & $81,58( \pm 0.011)$ \\
III - pH =10 & \\
IV - pH =9 & \\
A - 1 hora de agitação do extrato protéico solúvel & \\
B - 2 horas de agitação do extrato protéico solúvel \\
C - 1 hora de agitação da proteína precipitada \\
D - 2 horas de agitação da proteina precipitada \\
* resultados das análises em matéria seca com média de três repetições $( \pm$ desvio padrão $)$
\end{tabular}

\subsection{Concentrado protéico de torta desengordurada de castanha-do-pará - PROPARÁ}

A partir de resultados citados anteriormente, seguiram-se os seguintes parâmetros para a obtenção do PROPARÁ.

matéria-prima: torta desengordurada de castanha-do-pará

pH de precipitação protéica: 3,5 
relação matéria-prima/sol. de $\mathrm{HCl}: 1: 15(\mathrm{p} / \mathrm{v})$

tempo de agitação magnética: 3 horas a 60 rpm

modo de separação do precipitado/material solúvel: filtração a vácuo

secagem: proteína na forma isoelétrica em estufa de circulação de ar forçado a $40^{\circ} \mathrm{C}$ durante 3 horas.

- trituração: granulometria inferior à malha 100 da peneira da série "US Standard"

Cabe mencionar que a velocidade de agitação magnética da proteína precipitada foi a mínima necessária para manter o material em suspensão, evitando-se, dessa forma, uma possível desnaturação das proteinas. O concentrado foi seco com a proteina na forma isoelétrica para evitar perdas protéicas e também para que a secagem pudesse ser feita em estufa de circulação de ar forçado, pois uma vez neutralizado, a secagem deveria ser feita com um secador tipo "spray drier", segundo Santos, et al. 1978.

O rendimento em concentrado foi de $70 \%$ em relação ao peso da matériaprima e este apresentou cor branca levemente cremosa.

$\mathrm{O}$ teor de nitrogênio total do concentrado protéico mutiplicado por $\% \mathrm{~N} \mathrm{x}$ 5,46, foi $59,30 \%$ (Tabela 11). Este resultado não se enquadra na definição da Legislação Brasileira de Alimentos para concentrado protéico de soja. Contudo se aplicado o mesmo fator utilizado pela Legislação de 6,25 o teor de proteína será de $68 \%$ em base seca, um resultado que se aproxima da definição (ABIA, 1991). 
Tabela 11 - Composição química do PROPARÁ com aplicação das melhores condições estabelecidas nos ensaios preliminares. (ENSAIO 6) *

\begin{tabular}{c|c|c|c|c|c}
\hline Umidade & $\begin{array}{c}\text { Proteina bruta } \\
(\% \mathrm{~N} \times 5.46)\end{array}$ & Óleo & Carboidrato & Cinza & Fibra \\
\hline 8,94 & $59,30( \pm 0,0210)$ & $1,37( \pm 0.011)$ & 26,96 & $4,53( \pm 0.031)$ & 9,11 \\
\hline
\end{tabular}

*resultados das análises em matéria seca com média de três repetições ( \pm desvio padrão)

\subsection{Isolado protéico de torta desengordurada de castanha-do-pará - ISPARÁ}

A partir dos resultados anteriores, seguiram-se os seguintes parâmetros para a obtenção do ISPARÁ:

- matéria-prima: torta desengordurada de castanha-do-pará

- pH de extração protéica: 9,00

- relação matéria-prima/solução: $\mathrm{NaOH}: 1: 15(\mathrm{p} / \mathrm{v})$

- tempo de agitação magnética: 2 horas a $60 \mathrm{rpm}$

- pH de precipitação protéica: 4,00

- modo de separação do precipitado/material solúvel: filtração a vácuo

- secagem: proteína na forma isoelétrica em estufa de circulação de ar forçado a $40^{\circ} \mathrm{C}$ durante 4 horas.

- trituração: granulometria inferior à malha 100 da peneira da série "US Standard" 
O rendimento do isolado protéico foi de $35 \%$ em relação à matéria-prima e apresentou cor amarelo claro.

O isolado protéico apresentou um teor elevado de proteina de $81,58 \%(\% \mathrm{~N} \mathrm{x}$ 5,46) (Tabela 12), mas se multiplicarmos pelo mesmo fator da soja $(\% \mathrm{~N} \mathrm{x} \mathrm{6,25)} \mathrm{teremos}$ um teor de proteína de $93,38 \%$, resultado este que o classifica como tal, segundo a Legislação Brasileira de Alimentos.

Tabela 12 - Composição química do ISPARÁ com aplicação das melhores condições estabelecidas nos ensaios preliminares. (ENSAIO 7) *

\begin{tabular}{c|c|c|c|c|c}
\hline Umidade & $\begin{array}{c}\text { Proteína bruta } \\
(\% \mathrm{~N} \times 5,46)\end{array}$ & Óleo & Carboidrato & Cinza & Fibra \\
\hline 10,23 & $81,58( \pm 0,011)$ & $0,16( \pm 0,01)$ & 13,27 & $4,28(0,021)$ & 0,71 \\
\hline
\end{tabular}

*resultados das análises em matéria seca com média de três repetições ( \pm desvio padrão)

Cabe lembrar que este trabalho foi conduzido com base em métodos de obtenção de concentrados protéicos de várias origens protéicas, devido à inexistência de produtos protéicos obtidos da castanha-do-pará. Porisso a definição adotada para concentrado e isolado protéico foi a da Legislação Brasileira de Alimentos para produtos de soja (ABIA, 1991).

\subsection{Propriedades funcionais}

Todas as propriedade funcionais da TDCP, do Propará e do Ispará descritas neste trabalho foram determinadas em meios de $\mathrm{pH}$ próprio de cada produto. 


\subsubsection{Solubilidade do nitrogênio}

\subsubsection{Torta integral e torta desengordurada de CP}

O mesmo comportamento é observado nas curvas de solubilidade da torta integral e da torta desengordurada, haja vista a única diferença ser o teor de lipídeos (Figuras 9 e 10). A mínima solubilidade foi obtida entre os pH's 3 e 4, onde deve se encontrar o ponto isoelétrico das proteínas.

Segundo Lehninger (1976) a solubilidade da maioria das proteinas globulares é influenciada profundamente pelo $\mathrm{pH}$ do sistema. $\mathrm{O} \mathrm{pH}$ em que a proteína tem sua solubilidade mínima é seu $\mathrm{pH}$ isoelétrico, definido como o $\mathrm{pH}$ em que a molécula não apresenta carga elétrica efetiva e é incapaz de se deslocar em um campo elétrico. Nestas condições, não existe repulsão eletrostática entre as moléculas protéicas vizinhas e elas tendem a coalescer e precipitar.

A mais alta solubilidade foi atingida em $\mathrm{pH}$ alcalino $(\mathrm{pH}$ 12). A torta desengordurada apresentou solubilidade de $98,73 \%$ em pH 12, em comparação a 95,52\% conseguidos pela torta integral. Atribui-se o menor rendimento ao maior conteúdo de lipídeos da torta integral

O conhecimento da curva de solubilidade das matéria-primas (torta integral e torta desengordurada) foi a primeira providência tomada antes de iniciar a produção de concentrado e isolado protéico. Os dados sobre solubilidade são a base para aplicação do 
método adotado, no qual usam-se valores conhecidos de $\mathrm{pH}$ para precipitação e extração de protéina.

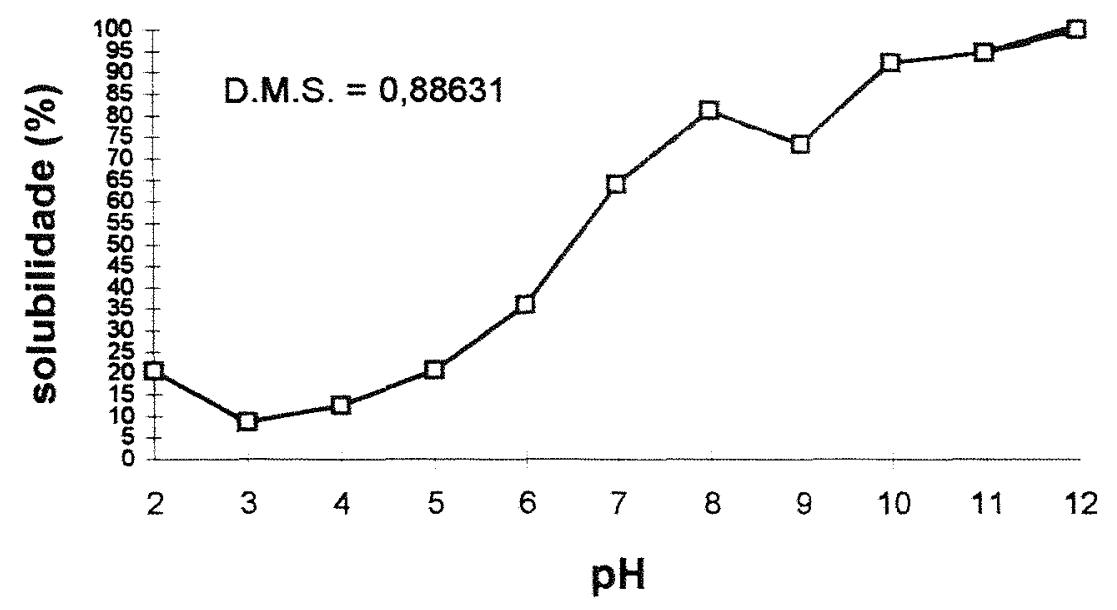

Figura 9 - Curva de solubilidade da torta integral de castanha-do-pará 


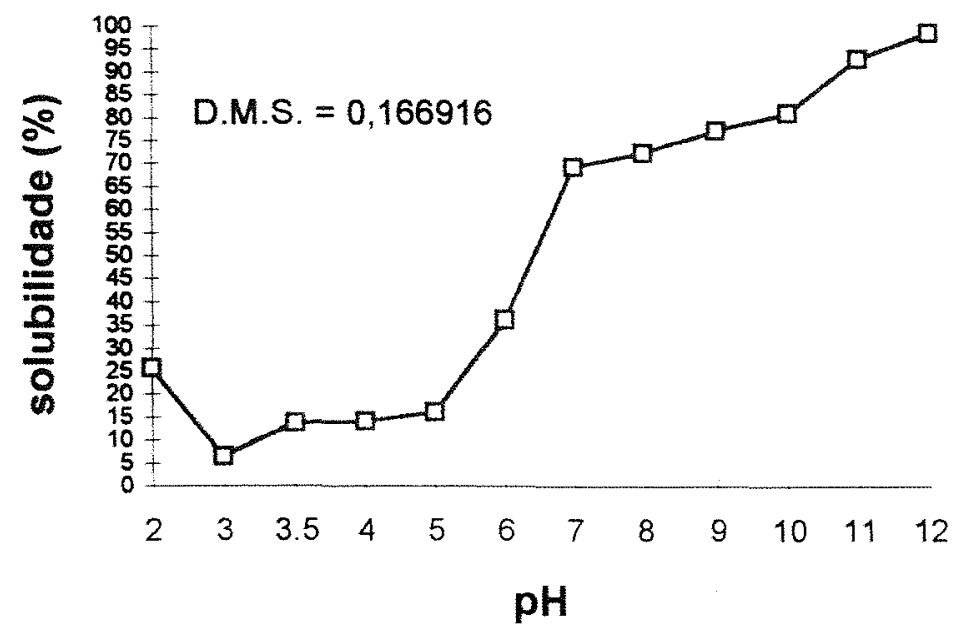

Figura 10 - Curva de solubilidade da torta desengordurada de castanha-do-pará

\subsubsection{Concentrado e isolado protéico de TDCP (PROPARÁ e ISPARÁ)}

Foram observadas diferenças nas curvas de solubilidade do PROPARÁ e do ISPARÁ, apesar de terem sido obtidos de uma mesma fonte protéica, a torta desengordurada de castanha-do-pará (Figuras 11 e 12)

Essas diferenças, possivelmente, foram devidas às variações nas condições do processamento. Segundo Kinsella (1979) a solubilidade é bastante dependente dos tratamentos aos quais as proteinas são submetidas e do meio em que são solubilizadas. 
O PROPARÁ tem a mais alta solubilidade em pH $12(86,86 \%)$ e solubilidade nula no ponto isoelétrico $(\mathrm{pH} 3)$. Esta solubilidade nula pode ter ocorrido devido ao longo tempo de agitação (3 horas) da proteína precipitada em solução de $\mathrm{HCl}(\mathrm{pH} 3,5)$. Para Kinsella (1979) embora a precipitação por acidificação, ou seja, por precipitação isoelétricà seja o método de recuperação de proteínas que provoca menor desnaturação e, consequentemente, menores alterações nas propriedades funcionais, a exposição prolongada à ação do ácido pode causar perda da solubilidade, o que já foi observado para proteínas de soja. Cantoral et al. (1985) também detectaram solubilidade nula no ponto isoelétrico quando produziram concentrado protéico de algumas leguminosas.

Em geral, o ISPARÁ apresenta maior solubilidade em comparação ao PROPARÁ e, segundo Hutton \& Campbell (1977), essa diferença de solubilidade pode ser explicada também pela presença de polissacarídeos no concentrado, que podem competir com as proteínas pela água disponivel.

O ISPARÁ apresentou boa solubilidade em pH 2 (49,11\%) e alta solubilidade no $\mathrm{pH} 12(87,84 \%)$. Próximo à região do ponto isoelétrico ele apresentou baixa solubilidade. Hutton \& Campbell (1977) e Wolf \& Cowan (1971) também observaram essa tendência.

Com estes dados podemos concluir que nem o concentrado, nem o isolado protéico de TDCP podem ser utilizados em bebidas devido à baixa solubilidade em $\mathrm{pH}$ ácido, porém podem ser utilizados na produção de pães, massas em geral ou alimentos semi-sólidos de acordo com Bartholomai, 1979. 


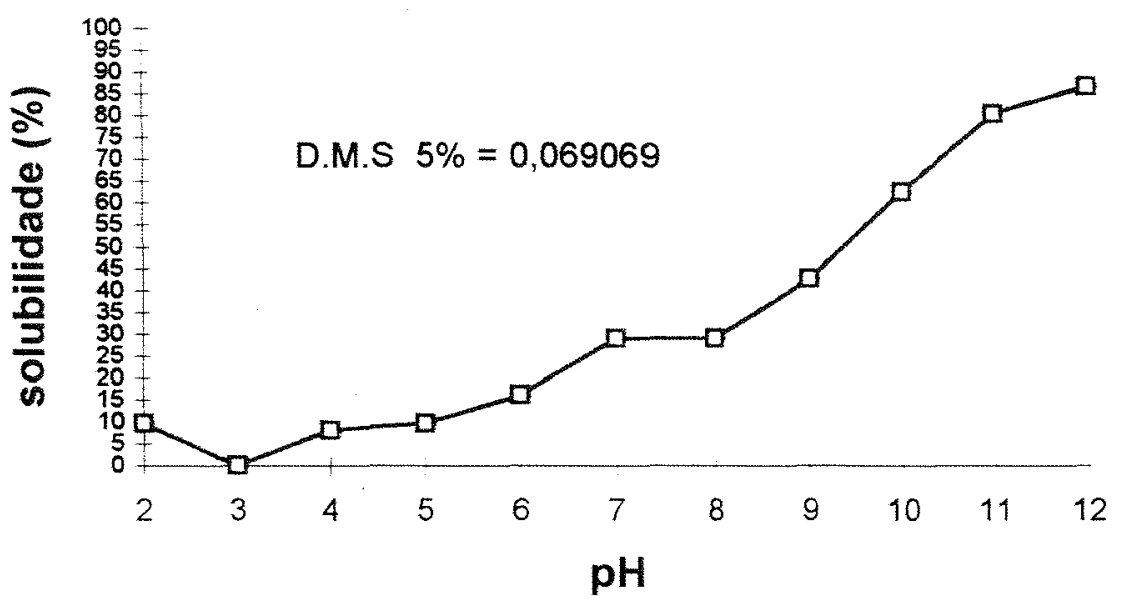

Figura 11 - Curva de solubilidade do PROPARÁ

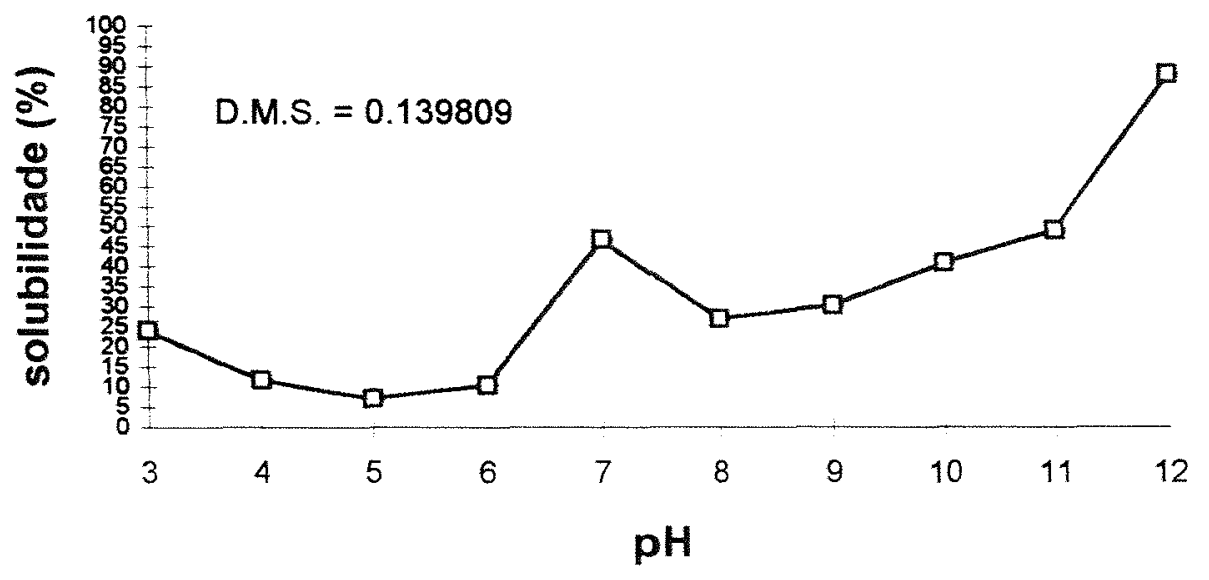

Figura 12 - Curva de solubilidade do ISPARÁ 


\subsubsection{Absorção de água}

O valor encontrado para a capacidade de absorção de água do PROPARÁ foi de $338,12 \%$, resultado superior em relação aos observados para concentrados de outras origens protéicas. Segundo Lin \& Humbert (1974) os concentrados protéicos de soja Promosoy e Isopro tem absorção de água de $196,1 \%, 227,3 \%$, e os concentrados protéicos DE-60 e DE-90, de girassol, 137,8\% e 203,0\%, respectivamente.

A capacidade de absorção de água do ISPARÁ foi de 149,6\%.

Bagnis (1984) verificou uma absorção de água de $179,4 \%$ para o isolado protéico de girassol. Lin \& Humbert (1974) encontraram $447,6 \%$ e $416,7 \%$ para os isolados de soja Supro 610 e Promine D respectivamente, para o isolado protéico de girassol DE-60 o resultado foi $155,1 \%$.

As diferenças encontradas para absorção de água entre os produtos, torta desengordurada de castanha-do-pará $(377,09 \%)$, PROPARÁ $(338,12 \%)$ e ISPARÁ $(149,7 \%)$, encontradas na Tabela 13 podem ser devidas à maior porcentagem de carboidratos contida na torta e no concentrado comparado ao isolado, segundo Ohren (1981).

Segundo Kinsella et al. (1985), componentes não protéicos podem afetar muito a absorção de água de um preparado protéico. A capacidade de absorção de água varia com a fonte protéica, composição e presença de carboidratos, lipídeos, sais, pH e pode ser influenciada por processamentos sofridos pela proteína com o aquecimento, alcalinização, etc. 
Em comparação aos concentrados e isolados protéicos de outras origens (Bagnis, 1984; Kinsella et al., 1985; Lin \& Humbert, 1974), verifica-se que o PROPARÁ e o ISPARÁ estão dentro da média de capacidade de absorção de água.

Os produtos protéicos de soja apresentam maior capacidade de absorção de água do que os de girassol e castanha-do-pará. Lin \& Humbert (1974) observaram que as proteinas de soja devem ser mais hidrofilicas que as de castanha-do-pará e girassol.

\subsubsection{Absorção de óleo}

As diferenças encontradas nos resultados de absorção de óleo da torta desengordurada de castanha-do-pará (174\%), do PROPARÁ (145\%) e do ISPARÁ (79\%), podem ser explicadas de acordo com as mesmas considerações tecidas para a absorção de água (Tabela 13).

Lin \& Humbert (1974) encontraram $92-133 \%$ e $226-254 \%$ de absorção de óleo para os concentrados de soja e girassol e $119-154 \%$ e $256 \%$ para os isolados de soja e girassol, respectivamente.

Estes resultados demonstram que o concentrado de TDCP tem capacidade de absorção de óleo muito parecida com a do concentrado de soja e que o concentrado de girassol apresenta proteínas com caracteristicas mais lipofilicas e por isso, maior absorção de óleo. 
Tabela 13 - Absorção de água e de óleo dos produtos de castanha-do-pará

\begin{tabular}{l|l|l}
\hline Produto & $\%$ Absorção de água * & $\%$ Absorção de óleo * \\
\hline TDCP & $327( \pm 0,05)$ & $174( \pm 0,03)$ \\
PROPARÁ & $338( \pm 0,07)$ & $145( \pm 0,06)$ \\
ISPARÁ & $149( \pm 0,07)$ & $79( \pm 0,07)$ \\
\hline
\end{tabular}

* média de trés repetições

\subsubsection{Capacidade de formação de espuma e estabilidade}

A capacidade de formação de espuma é útil em sistemas de alimentos que requeiram aeração para propósitos de estética, textura ou fermentação (Betschart, 1979).

Os dados de capacidade de formação de espuma dos produtos de torta desengordurada de castanha-do-pará foram expressos em aumento do volume provocado pelo batimento (Tabela 14).

O PROPARÁ obteve um aumento de volume de aproximadamente $10 \%$ e o ISPARÁ, de $100 \%$. Sgarbieri (1996) conseguiu $64,3 \%$ de aumento de volume para o concentrado de feijão e $7,7 \%$ para o isolado de feijão. Os produtos de castanha-do-pará são melhores formadores de espuma que os produtos protéicos de feijão.

A torta desengordurada de castanha-do-pará apresentou melhor capacidade de formação de espuma que o PROPARÁ, embora tenha $20 \%$ a menos de proteína. 
Segundo Lin \& Humbert (1974) outros componentes não protéicos podem ajudar na formação de espuma.

A estabilidade da espuma é importante porque o sucesso de um agente espumante depende de sua habilidade de manter a espuma por mais tempo possivel (Lin \& Humbert, 1974). Pode-se observar pela Tabela 14 que as espumas formadas pelo ISPARÁ são mais estáveis que aquelas obtidas com o PROPARÁ. De acordo com Lin \& Humbert (1974) a exposição da proteina a condições extremas de alcalinidade (pH 11 12) durante o processo de produção do isolado protéico pode melhorar a capacidade de formação e estabilidade da espuma. Segundo Cheftel et al. (1989) para que espuma protéica seja estável, necessita-se que em torno de cada bolha de gás se forme uma película protéica espessa, coesa, elástica, contínua e impermeável ao ar.

Tabela 14 - Capacidade de formação e estabilidade da espuma dos produtos de castanhado-pará.

\begin{tabular}{l|l|lllll}
\hline Produto & $\%$ Aumento do volume & \multicolumn{5}{|c}{ Volume de espuma após repouso $(\mathrm{ml})$} \\
& & $1 \mathrm{~min}$ & $5 \mathrm{~min}$ & $10 \mathrm{~min}$ & $30 \mathrm{~min}$ & $60 \mathrm{~min}$ \\
\hline TDCP & $59,9( \pm 0,02)$ & 161,5 & 150,0 & 130,0 & 120,0 & 105,0 \\
PROPARÁ & $9,90( \pm 0,04)$ & 109,0 & 107,0 & 105,0 & 103,0 & 102,0 \\
ISPARÁ & $170,0( \pm 0,05)$ & 272,0 & 272,0 & 271,0 & 270,0 & 270,0 \\
\hline
\end{tabular}

\pm desvio padrão 


\section{CONCLUSÕES}

A extração do óleo da torta integral de castanha-do-pará tornou possivel sua utilização como matéria-prima para a obtenção de concentrados e isolados protéicos.

A obtenção de concentrado e isolado (PROPARÁ e ISPARÁ) com 59\% e $81 \%$ de proteina ( $\mathrm{N} \times 5,46)$, respectivamente, foi conseguida através de adaptações e modificações das metodologias já existentes na literatura.

A torta desengordurada de castanha-do-pará e o PROPARÁ não apresentaram boa capacidade de formação de espuma. O ISPARÁ apresentou boa capacidade de formação e estabilidade de espuma, com possibilidade de aplicação em produtos tais como bolos, suspiros, coberturas de doces, etc.

Tanto a TDCP como o PROPARÁ e ISPARÁ devem encontrar aplicação bastante grande, devido à solubilidade, absorção de água e óleo apresentarem se comparáveis à de produtos protéicos de outras origens protéicas. Contudo a TDCP já é um produto de utilização viável tanto direto na alimentação como na adição de formulações, pois apresentou um teor de proteina bastante alto $(47 \%)$ e boas propriedades funcionais a um custo mais baixo que seus produtos derivados.

Estudos das propriedades anti-nutricionais são necessárias para a conveniência de consumo dos produtos discutidos neste estudo. 


\section{REFERÊNCIAS BIBLIOGRÁFICAS}

AMERICAN OIL CHEMISTS' SOCIETY - Official methods and recommended practices. 4.ed. Champaign, 1991.

ANTUNES, A. J.; MARKAKIS, P. Protein suplementation of navy beans with Brazil nuts. Journal Agricultural Food Chemistry v.25 n.5, p. 1096-1098, 1977.

ASSOCIAÇÃO BRASILEIRA DAS INDÚSTRIAS DE ALIMENTAÇÃO. Compêndio da Legislação de Alimentos, São Paulo, 1991, v.2/A, p.7-33(38).

ASSOCIATION OF OFFICIAL ANALYTICAL CHEMISTS - Official methods of analysis. 16ed., Arlington, 1995.

BAGNIS, C.G. Isolado protéico de girassol - obtenção e propriedades. Campinas, 1984, 97p. Tese (Mestrado), Faculdade de Engenharia de Alimentos, Universidade de Campinas/SP.

BARTHOLOMAI, G.B. Isolados protéicos de origem vegetal - propriedades funcionais de um isolado protéico de feijão branco (Phaseolus vulgaris). Indústria Alimentar, v.4, n.19/20, p.40-46, 1979.

BARTHOLOMAI, G.B. ; PILOSOF, A.M. Propriedades funcionales de fuentes proteicas de origem vegetal - aplicacion en alimentos. La Alimentacion Latinoamericana, v.19, n.152, p.44-54, May/Junio, 1985.

BAU, H.M; MOHTADI-NIA, D.J.; MEJEAN, L.; DEBRY, G. Preparation of colorless sunflower protein products: Effects of processing on physicochemical and nutritional properties. Journal of the American Oil Chemists' Society, v.60, p.1141-1148, June/1983. 
BEROT, S.; CHENU, M.; COUTRET, J.; GUEGUEN, J. Cottonseed protein rich products from glandless African varieties 1. Pilot-plant scale production of protein concentrates. Science des Aliments, v.15, n.3, p.203-215, 1995.

BICKOFF, E.M.; BOOTH, A.N.; DE FREMERY, D., EDWARDS, R.H.; KNUCKLES, B.E.; MILLER, R.E.; SAUNDERS, R.M.; KOHLER, G.O. Nutritional evaluation of alfafa leaf protein concentrate. In: FRIEDMAN, M. Protein nutritional quality of foods and feeds, New York: Marcel Dekker, 1975. p.319-340.

CAMPBELL, M.F.; KRAUT, C. W.; YACKEL, W.C.; YANG, A.H.S. Soy protein concentrate. In: ALTSCHUL, A. M.; WILCKE, H. L., New protein foods, 2.ed. Orlando: Academic Press, 1985, v.5, cap.9, p.301-337.

CANELlA, M.; CASTRIOTTA, G.; SODINI, G. Proprietá funzionali di prodotti di girasole dopo estrazione dei pigmenti fenolici con butanolo acido. Rivista Italiana delle Sostanze. Grasse, n.54, v.2, p.73-6, 1977.

CANTORAL, R.; FERNANDES, A.Q.; MARTINEZ, A.; MACARULLA, M.T., Estudio comparativo de la composición y el valor nutritivo de semillas y concentrados de proteina de leguminosas. Archivos Latinoamericanos de Nutricion, v.45, n.3, p.242-248, 1995.

CHEFTEL, J.C.; CUQ, J. L.; LORIENT, D. Proteínas alimentarias - bioquímica, propriedades funcionales, valor nutritivo, modificaciones químicas. Zaragoza: Acribia, 1989. 346p.

CHEN B.H-Y.; MORR, C.V. Solubility and foaming properties of phytate-reduced soy protein isolate. Journal Food Science, v.50, n.4, p.1139-1142, 1985.

COGAN, U.; YARON, A.; BERK, Z.; MIZRAHI, S. Isolation of soybean protein: effect of processing conditions on yields and purity. Journal of the American Oil Chemists' Society, v.44, p.321-324, May 1967. 
COSTA, D.; MOTA, S. Beneficiamento das castanhas-do pará para fins alimentares. Cultura Médica, v.4, n. 3-4, set./out. 1942.

DIPACK, K.; KUMAR, K.D. Functional properties of rapeseed protein products with varying phytic acid contents. Journal of Agricultural Chemistry, v.34 p.775777, 1986.

DURÃO, J.C.O. Anotações bibliográficas e considerações sobre aspectos tecnológicos In : CONFERÊNCIA NACIONAL DA CASTANHA-DO-BRASIL, 1., s.n.t., 12p.

ELDRIDGE, A. C; Organic solvent treatment of soybeans and soybean fraction. In: SMITH, A. K.; CIRCLE, S. J. Soybeans: chemistry and technology, Westport, AVI Publi, 1978. v.1, cap.5, p.145-157.

ELIAS, L.G.; BRESSANI, R. The nutritive value of Brazil nut oil. Journal of the American Oil Chemists' Society, v.38, n.8, p.450-452, 1961.

ENSMINGER, A. H; ENSMINGER, M. E; KONLANDE, J. E; ROBSON, J. R. K. Foods \& nutrition encyclopedia, 2 ed.: CRC Press, 1994., v.2, p. 1860-1886.

FUKUSHIMA, D. Denaturation of soybean proteins by organic solvents. Cereal Chemistry, v.46, n.2, p.156-163, March 1969.

GOMES, F.P. Curso de estatística experimental, 13 ed., Piracicaba/SP, 1990, 467p.

HERMANSSON, A. M. Methods of studying functional characteristics of vegetable proteins. Journal of the American Oil Chemists' Society, v.56, n.3. p.272$284,1979$.

HUTTON, C.W. ; CAMPBELL, A.M. Functional properties of a soy concentrate and a soy isolate in simple systems. Journal of Food Science, v.42, n.2, p.454-456, 1977

KINSELLA, JE:; DAMODARAN, S; GERMAN, A. B. Physicochemical and functional properties of oilseed proteins with emphasis on soy proteins. In: 
ALTSCHUL, A. M.; WILCKE, H.L New protein foods, 2.ed. Orlando: Academic Press, 1985. v.5, cap.V, p.107-79.

KNORR, D. Effect of recovery methods on yield, quality and functional properties of potato protein concentrates. Journal of Food Science, v.45, n.5, p.1183-1186, 1980

KOLAR, C. W.; RICHERT, S. H.; DECKER, C. D..; STEINKE, F. H.; ZANDEN, A. R. J. V. Isolated soy protein. In: ALTSCHUL, A. M.; WILCKE, H. L., New protein foods, 2.ed. Orlando: Academic Press, 1985, v.5, cap.8, p.259-299.

LIN, M.J.Y; HUMBERT, E. S. Certain functional properties of sunflower meal products. Journal of Food Science, v.39, n.1, p.368-370, 1974.

LOCKMILLER, N.R. Increased utilization of protein in foods. Cereal Science Today v.18, p.77-81, 1973.

MENEZES, T. J. B. A castanha-do-Pará na indústria de alimentos. Boletim do Centro Tropical de Pesquisas e Tecnologia de Alimentos, n.9, p.23-30, 1967.

MEYER, E. W. Oilseed protein concentrates and isolates. Journal of the American Oil Chemists' Society, v.48, n., p.484-488, Sept. 1971.

MOURA, E. C. V.; ZUCAS, S. M. Ensaio nutricional da proteina de soja suplementada com farinha de castanha-do-Pará. Revista da Associação Brasileira da Industria de Alimentos, v.57, p.6-17, 1981.

MUSTAKAS, G. C.; KIRK, L. D.; GRIFFIN JR., E. L. Flash desolventizing defatted soybean meal washed with aqueous alcohols to yield a high-protein product. Journal of the American Oil Chemists' Society, v.39, p.222-226, April 1961.

NORMAS ANALÍTICAS DO INSTITUTO ADOLFO LUTZ. Métodos químicos e fisicos para análise de alimentos, 3 ed., São Paulo, 1985. 533p.

OHREN, J.A. Process and product characteristics for soya concentrates and isolates. Journal of the American Oil Chemists' Society, v.58, n.3, March, 1981. 
OLIVEIRA, J. E. D.; SANTOS, A. C.; WILSON, E. D. Nutrição básica, São Paulo: Sarvier, $1989,58 \mathrm{p}$.

OSBORNE, T. B.; The vegetable proteins., London: Longmans Green., 1918, 125p. (Monographs on Biochemistry)

PECHINICK, E; BORGES, P.; SIQUEIRA, R. Estudo sobre a castanha-do-pará. Arquivo Brasileiro de Nutrição, v.7, n.1, p.7-41, 1950.

PEREIRA, P. L. Extratos solúveis da castanha-do-Brasil (Bertholletia excelsa, H.B.K.). Campinas, 1976, 43p. Tese (Mestrado), Faculdade de Engenharia de Alimentos, Universidade de Campinas/SP.

ROSSI M., C. PERI \& M.RIVA. Produzione di farine proteiche da girasole. II. Estrazione combinata dell'oleo e dell'acido clorogenico. Rivista Italiana Sostanze delle Grasse, n.57, p.509-512, 1980.

PHILLIPS, L.G.; HAQUE, Z; KINSELLA, J.E. A method for the measurement of foam formation and stability. Journal of Food Science, v.52, n.4, p.1074-1075, 1987.

REGITANO-d'ARCE, M. A. B.; ASSIS, R. de P.; LIMA, U de A. Functional properties of sunflower seed meal obtained by ethanol extration. Archivos Latino Americanos de Nutrición, v.14, n. 1, p.29-32, 1994.

ROTENBERG, B.; IACHAN, A. Estudo da proteína da castanha-do-pará. Informativo do Instituto Nacional de Tecnologia , v.8, n.7, p.22-24, 1975.

SANTOS, L.C.; COSTA, S.J.; ARCKOOL, P.B.; VITALI, A.A. Produção de concentrado e isolado protéico de soja. Coletânea do Instituto Tecnológico de Alimentos, v.9, p.85-103, 1978.

SGARBIERI, V. C. Proteínas em alimentos protéicos - propriedades, degradações, modificações. São Paulo: Livraria Varela, 1996, p. 259-334. 
SILVA, M.T.; TURATTI, J.M. Extração de óleo de soja com etanol. Coletanea do Instituo de Tecnologia de Alimentos, v.21, n.1, p.73-89, jan./jun. 1991.

SOSULSKI, F.; HUMBERT, E.S.; BUI, K.; JONES, J.D. Functional properties of rapeseed flour, concentrates and isolate. Journal Food Science, v.41, n.6, p. 1349-1376, 1976.

SOUZA, A.H. Castanha-do-pará. S.I.A. Ministério da Agricultura. Estudos Técnicos, n.23, Rio de Janeiro, 1963.

STRANO, H.C.V.G. Obtenção e caracterização de concentrado protéico de aguapé (Eichhornia crassipes) Piracicaba, 1987, 129p., Tese (Mestrado), Escola Superior de Agricultura 'Luiz de Queiroz". Universidade São Paulo.

SUN, S. S. M.; ALTENBACH, S. B.; LEUNG, F. W. Properties, biosynthesis and processing of a sulfur-rich protein in Brazil nut (Bertholletia excelsa H.B.K.), European Journal of Biochemistry, v.162, p.477-483, 1987.

WOLF, W.J. Purification and properties of the proteins. In: Soybean Chemistry and Technology,. Westport: AVI Publ, 1972, v. 1, p.93-143.

WOLF, W.J. ; COWAN J.C. Soybeans as a food source. CRC Critical. Reviews in Food Technology, v.2, p.81-88, 1971.

WOODROOF, J.G. Tree nuts - Production, Processing, Products. Westport: AVI Publ., 1979.

ZUCAS, S. M.; SILVA, E. C. V.; FERNANDES, M. J. Farinha de castanha-do-pará: valor de sua proteína. Revista de Farmácia e Bioquimica da Universidade São Paulo, v.13, n.1, p.133-144, jan/jun. 1975. 